\title{
非經口的二注入七ル大動脈壁細胞成分 ノ血壓及血液瓦斯二及ボス影響二就テ
}

\author{
第一篇 内被細胞成分, 血液互斯二 \\ 及ボス影響二就テ
}

東京帝國大學傅染病研究所附澬紫院(主任宮川教授)

砰究生 住 藤 猪 一 郎

\begin{tabular}{|c|c|}
\hline 目 次 & 第一 蒸餾水注入，場合 \\
\hline 第一章 緒 言 & 第二 同種性腹膜_上皮細胞戊分注入，場 \\
\hline 第二章 實驗材料及ビ賽驗方法 & 合 \\
\hline 第三章 實驗成績 & 第三 同種性胃粘膜上皮細胞成分注入， \\
\hline 第一節 健康家兔動脈血瓦斯含有量 & 場合 \\
\hline $\begin{array}{c}\text { 第二節 異種性大動脈內被細胞成分注入， } \\
\text { 場合 }\end{array}$ & $\begin{array}{l}\text { 第四 同種性渴粘膜上皮細胞成分注入， } \\
\text { 場合 }\end{array}$ \\
\hline 第一 適當刺戟量注入，場合 & 第四章 總括考按 \\
\hline 第二 大量注入，場合 & 第五章 結，論 \\
\hline 第三節 對照試驗 & 主要文獻 \\
\hline
\end{tabular}

\section{第一童 緒 聿}

血液中二含有セラル、瓦斯八酸榇及ビ炭酸瓦斯ニシテ其，含有量八動脈血. 静眽血二於テ夫々 相異アルモ生理的狀態ニアリテヘ夫タ略:一定セリ。而シテ肺胞壁ヨ隔テ、外界ョリ酸素ノ攝取

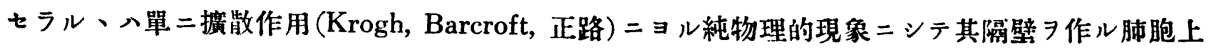
皮細胞及ビ血管內被細胞八何等之二與ラザルモノナリト七ラレタリ。然ル = Haldane 一派二依 レバ安静時二八動脈內卜肺胞內卜，酸素分脳八间一ナルモ肺胞內，酸素缺乏スルカ又八勞働二

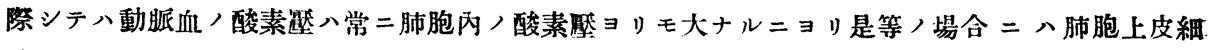
胞が主働的二酸素习血中分泌スルコトヨ主張セリ。近時 Joachima Schjering 八賽驗的=Pneu monose，像 生ゼル場合郎千肺臟上皮細胞二變化 7 生ズル場合二八瓦斯交換作用ハ障碍セラレ 酸素攝取困難二䧂り從ツテ酸素量, 減少 $\exists$ 來スト云へリ。更二佐滕敏氏八肺腈上皮細胞卜血液瓦 斯卜, 關係 $习$ 檢索シ生體二非經口的二肺瀻實質細胞乳劑 $习$ 注入七シ

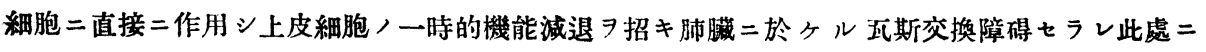
血液酸素含有量, 減少卜血液岸酸瓦斯含有量, 增加ト 7 來スント

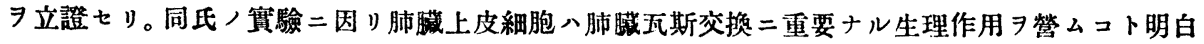

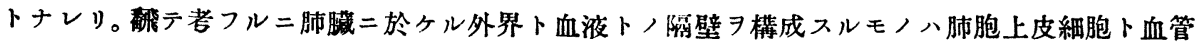

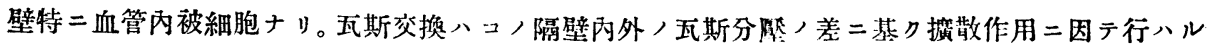


佐藤 =非經口的二注入セル大動脈壁細胞成分，血歷及血液瓦斯二及ボ ス影䇾二就テ 803

ルト同時二肺胞上皮細胞ノ生理機能モ重要ナル關係ヨ有スルモノトセパ血管內被細胞モ單二五 斯习通過セシムルノミナラズ何等カノ重要ナル生理機能习營爲スルモノニ非ズヤノ疑习生ゼリ。 從來成書二記载七ラレタル處二依レバ血管內被細胞, 生理作用八凝血作用习支配スルモノト七 ラレ一度血管內被紬胞障碍七ラル、場合へ㨁二血液/凝固作用 7 催進セシム可キモノトセラレ タリ。交獻习涉猛セルモ血液瓦斯卜ノ關係习記载セルモノナシ。

茲二於テ余八血管內被細胞乳剌习生䯏二非經口的二注入シ之二因りテ其，生體/血液瓦斯八

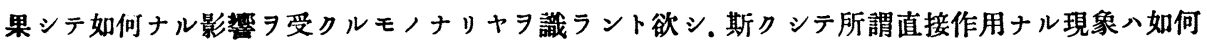
ナル程度二發現シ延テハ血管內被細胞ノ瓦斯交換ニ對スル意義ヨ探究スベク本賽驗二著手セり。

\section{第二章＼cjkstart寞驗材料及ビ寅醶方法}

1. 注射材料及其製法. 注射材料トシテ八屠牛場ヨリ得タル新鮮ナル牛大動脈 使 用七リ大動脈队被細胞ノ剝雄ハ容易ナラザルキ以テ其乳劑ノ製造ハ甚ダ困難ナルモノ ナリ。Dungern 氏八動物ノ新鮮氣管ヨリ䫀毛上皮み剝離シテ生理的食監水ニテ浮游

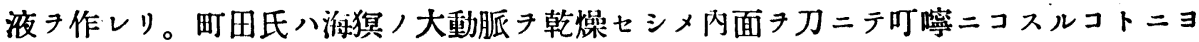
リテ血管內被細胞ヨ得タリト云へリ。然レドモ其ノ量極メテ僅少ナリシト云ヒ前者二 於テハ一定ノ面積ヨ有スル氣管壁ヨリ剥離シタル量き單位トナシ後者八遠心沈澱セル 度ア以テ單位トナセリ。

余ハ次ノ方法ニョリテ大動脈內被細胞乳剂テ製セり。最初二大動脈ノ外部二附著セ ル脂肪テ出來得ルダケ四嚀二除去シ之テ縱二開キ隇菌蒸餾水二テ數回洗滌ス．然ルト キハ動脈内外二附著セル小量/血液キ大部分除去スルキ得ベシ。直二喴菌ガーゼ上二 擴ゲ附著セル水分き充分二拭七乾燥セザル間二解剖刀二テ內面き輕ク磨擦スルトキハ

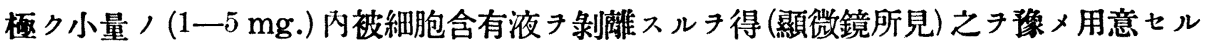
减菌小「バラフィン」紙上二採り重量き測定セリ。カ、ル操作き反復シ必要量ノ內被細

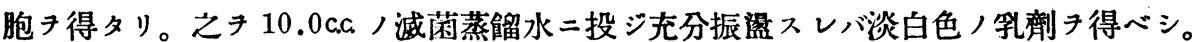
之チ氷室中二貯藏シ凡 12 時間乃至 18 時間後二取り出シ動物ノ體重二應ジテ必要量 分于適當ノ隇菌蒸餾水ヲ注加シ全量き10 c.c.トナシ使用セリ。

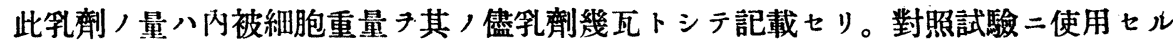

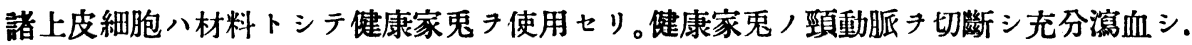
腹膜上:皮細胞ハ直二無菌的開腹術き施シ洗條スルコトナク腹膜上皮き前記ノ場合ト同 樣ノ方法ニョリテ採取セリ．胃腸上皮細胞八胃腸キ取リ出シ内容き除去シ充分洗條七 几後同樣ノ力法ニョリテ上皮細胞チ剝離シ前記同樣ノ方法ニテ乳劑き製シ實驗二供七 リ。以.上ノ操作ハ總テ無菌的ナリトス。

2. 實驗動物。實驗動物トシテハ其體重略 32 氐内外，健康家鬼き撰ビ多クハ毛白 


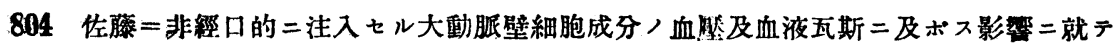

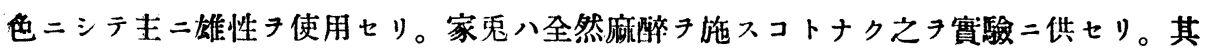
ノ飼養場. 食飰及ビ食事ノ時間八可及的最善ノ注意き拂七タリ。

3. 實驗方法，注射液ハ其ノ全量キ10.0c.c.トナシ注入容積ノ差二因りテ誘發七ラル ル動物ノ血液稀䆁度キ一定ナラシメ且攝氏 37 度二加溫シ動物二對シ盜度/影掣キ少

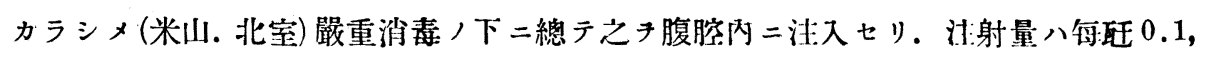
$0.05,0.01 ， 0.005$ 瓦使用セり。斯クシテ注入前後二於ヶル血液瓦斯量ノ變化き夫 々時間的二且長期二互りテ觀察セり。

血液瓦斯含有量, 测定八酸素及炭酸瓦斯共= Barcroft 氏, 方法 (Barcroft, Barcroft \& Robert, Hoffmann, Bohr, Bürker) =依り其血液瓦斯分析器, 大型用七 動脈血二就テ每常之キ實驗七り。先ジ動物キ早朝空腹時二體重キ測定シ直二固定器二 背位二固定シ心臟部及ビ腹部二於テ其ノ毛ョョク剪除シ夏期以外二在リテハ胸腹部 普通青梅綿二テ充分緾包シ異常位二於ヶル外界溫度ノ影響(北室) 避ヶ 30 分乃至 1 時間之き放置シ家兔ノ束縛二因ル不安狀態特二呼吸運動ノ再ビ安靜二復歸スルチ待チ 實驗子開始セリ。採血方法八心臟穿刺二依り常二充分消表: ル同一注射器キ用七煮沸 隇菌七ル $5 \%$ 枸䋇酸曹達溶液二テ其, 內面キ潤シ防凝, 手段トナシ然ル後嚴重消毒,

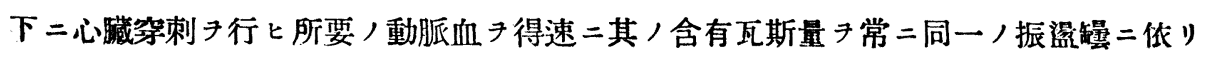
テ测定セリ。心臟穿刺二當り誤テ右心室穿刺セル場合二ハ內出血ヨ招來セルコト多 ク從テ瓦斯含有量ノ動播フ來スガ故二實驗チ中止シ記载セザリキ。

\section{第三章 實醶成綪}

\section{第一節 健康家鬼動脈血瓦斯含有量}

余八健康家鬼動脈血瓦斯含有量 7 時間的且 ツ長期二互リテ觀察セリ。郎チ第 1 表二 揭グル如ク健康家鬼動脈血酸素總容量八筫驗第 1 日二於テ時間的ニ八概シテ著シキ笕

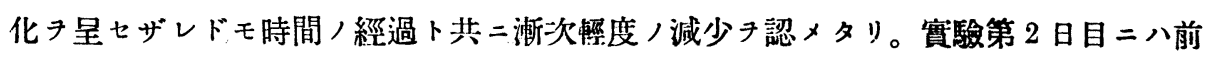
日ヨリ更二幾分減少シ：日ナ逐テ減少テ來タセドモ(時二減少セザルモノアリ)第 2 週 二於テ最低二達シソレヨリ漱次增加シ恢復二向七第 3 週ノ終リニ於テハ殆ド正常二復 歸セルモノ、如シ。酸素不飽和度二八第 1 日目ニ於テハ著明ノ變化き認メザレドモ賽 驗開始後 2-3 時間頃幾分增加キ涊メタルモノアリ(No. 25, No. 27) 全經過中著明 變 化き呈セズト雖モ多少ノ動播八冕レザル所ナリ。前述セルガ如ク酸素不能和度二著明 ノ變化フ認メザレバ從テ酸素含有量ハ酸素總容量ト隨伴シテ變動シ第 1 日及ビ第 2 日 目二幾分ノ減少チ認ムルニ過ギズ。炭酸瓦斯ハ血液中ニアリテハ酸素ノ如ク比較的安 
佐藤=非經口的二注入セル大動脈壁細胞成分，血盟及血液瓦斯二及ボス影響二就テ 805

第 一 表

\begin{tabular}{|c|c|c|c|c|c|c|c|c|c|c|}
\hline 月 日 & 實驗日 & 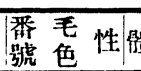 & 重 (硅) & $\begin{array}{l}\text { 時 } \\
\text { 時 }\end{array}$ & $\begin{array}{l}\text { 閔 } \\
\text { 分 }\end{array}$ & $\begin{array}{l}\text { 酸素不 } \\
\text { 飽和度 }\end{array}$ & 酸素容量 & $\begin{array}{l}\text { 酸素念 } \\
\text { 旦 }\end{array}$ & $\begin{array}{l}\text { 宸酸瓦斯 } \\
\text { 合有量 }\end{array}$ & 曼素貧 \\
\hline 9,26 & 1 & 21 白 우 & 2,080 & 11 , & 30 & 0.021 & 0.105 & 0.081 & 0.375 & 80 \\
\hline & & & & 12 & 30 & 0.022 & 0.101 & 0.079 & 0.378 & 78 \\
\hline & & & & 1 & 35 & 0.020 & 0.100 & 0.080 & 0.360 & 80 \\
\hline & & & & 2, & 24 & 0.021 & 0.096 & 0.075 & 0.341 & 78 \\
\hline & & & & 3 & 25 & 0.021 & 0.104 & 0.083 & 0.420 & 80 \\
\hline 10,10 & 1 & |22薄荣우 & 1,920 & 11, & 00 & 0.033 & 0.131 & 0.098 & 0.456 & 75 \\
\hline & & & & 12 & 10 & 0.022 & 0.124 & 0.102 & 0.467 & 82 \\
\hline & & & & 1, & 10 & 0.027 & 0.128 & 0.101 & 0.460 & 79 \\
\hline & & & & 2 & 10 & 0.036 & 0.128 & 0.092 & 0.442 & 72 \\
\hline & & & & 3 & 10 & 0.031 & 0.128 & 0.097 & 0.427 & 76 \\
\hline 10,11 & 2 & & 1,820 & 10 & 40 & 0.013 & 0.106 & 0.093 & 0.439 & 88 \\
\hline 10,13 & 4 & & 1,720 & 10 & 45 & 0.035 & 0.095 & 0.060 & 0.497 & 63 \\
\hline 10,15 & 6 & & 1,640 & 10 & 00 & 0.015 & 0.106 & 0.091 & 0.342 & 86 \\
\hline 10,24 & 1 & 23 白 우 & 1,900 & 12 & 00 & 0.029 & 0.122 & 0.093 & 0.458 & 76 \\
\hline & & & & 1 & 30 & 0.028 & 0.118 & 0.090 & 0.397 & 76 \\
\hline & & & & 2 & 30 & 0.026 & 0.117 & 0.091 & 0.418 & 78 \\
\hline & & & & 3 & 30 & 0.031 & 0.111 & 0.080 & 0.384 & 72 \\
\hline & & & & 4 & 30 & 0.028 & 0.114 & 0.086 & 0.397 & 74 \\
\hline & & & & 5 & 30 & 0.030 & 0.098 & 0.068 & 0.397 & 70 \\
\hline 10,25 & 2 & & 1,770 & 10 & 00 & 0.025 & 0.101 & 0.076 & 0.429 & 75 \\
\hline 10,27 & 4 & & 1,680 & 3 & 00 & 0.027 & 0.103 & 0.076 & 0.402 & 74 \\
\hline 10,29 & 6 & & 1,770 & 4 & 00 & 0.023 & 0.107 & 0.084 & 0.463 & 78 \\
\hline 12,17 & 1 & 25 白 $\quad$ 占 & 2,100 & 11 , & 15 & 0.015 & 0.111 & 0.096 & 0.365 & 82 \\
\hline & & & & 12 & 20 & 0.023 & 0.106 & 0.083 & 0.366 & 78 \\
\hline & & & & 1 , & 30 & 0.024 & 0.107 & 0.083 & 0.391 & 78 \\
\hline & & & & 2 & 30 & 0.019 & 0.107 & 0.088 & 0.379 & 82 \\
\hline & & & & 3 & 40 & 0.021 & 0.106 & 0.085 & 0.384 & 80 \\
\hline & & & & 4 & 40 & 0.029 & 0.106 & 0.077 & 0.385 & 73 \\
\hline 12,18 & 2 & & & 9 & 50 & 0.021 & 0.101 & 0.080 & 0.395 & 79 \\
\hline 12,20 & 4 & & & 11 , & 00 & 0.023 & 0.089 & 0.066 & 0.439 & 73 \\
\hline 12,22 & 6 & & & 11, & 00 & 0.015 & 0.078 & 0.063 & 0.477 & 80 \\
\hline 12,25 & 9 & & & 2 & 20 & 0.019 & 0.096 & 0.077 & 0.401 & 80 \\
\hline 12,27 & 11 & & & 1, & 40 & 0.018 & 0.098 & 0.080 & 0.322 & 82 \\
\hline 12,31 & 15 & & & 1, & 50 & 0.022 & 0.103 & 0.081 & 0.450 & 79 \\
\hline 1,6 & 21 & & & 1, & 30 & 0.020 & 0.100 & 0.080 & 0.384 & 80 \\
\hline 1,8 & 23 & & & 1, & 40 & 0.019 & 0.110 & 0.091 & 0.477 & 83 \\
\hline 1,12 & 27 & & 2,200 & 1, & 35 & 0.018 & 0.112 & 0.094 & 0.404 & 84 \\
\hline 1,14 & 29 & & 2,090 & 4 & 00 & 0.023 & 0.118 & 0.095 & 0.438 & 80 \\
\hline 1,17 & 32 & & 2,060 & 2, & 30 & 0.023 & 0.116 & 0.093 & 0.446 & 80 \\
\hline
\end{tabular}




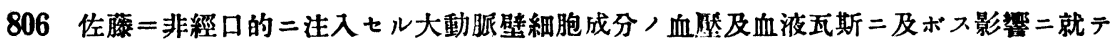

\begin{tabular}{|c|c|c|c|c|c|c|c|c|c|}
\hline 1,20 & 35 & & 2,090 & 2,30 & 0.022 & 0.116 & 0.094 & 0.394 & 81 \\
\hline 1,22 & 37 & & 2,070 & 2,40 & 0.023 & 0.107 & 0.084 & 0.383 & 79 \\
\hline 1,26 & 41 & & 2,080 & $2,5 \check{\jmath}$ & 0.019 & 0.106 & 0.087 & 0.463 & 82 \\
\hline 1,28 & 43 & & 2,080 & 2,10 & 0.019 & 0.104 & 0.085 & 0.462 & 82 \\
\hline 1,31 & 46 & & 2,230 & 10,30 & 0.022 & 0.107 & 0.085 & 0.422 & 79 \\
\hline \multirow[t]{6}{*}{$1, \quad 7$} & \multirow[t]{6}{*}{1} & \multirow[t]{15}{*}{27 白 $\boldsymbol{5}$} & \multirow[t]{6}{*}{3,010} & 11,20 & 0.019 & 0.137 & 0.118 & 0.424 & 86 \\
\hline & & & & 12,40 & 0.018 & 0.134 & 0.116 & - & 87 \\
\hline & & & & 1,40 & 0.021 & 0.139 & 0.118 & 0.378 & 85 \\
\hline & & & & 2,35 & 0.019 & 0.124 & 0.105 & 0.384 & 85 \\
\hline & & & & 3,30 & 0.020 & 0.123 & 0.103 & 0.371 & 84 \\
\hline & & & & 4,30 & 0.022 & 0.129 & 0.107 & 0.376 & 83 \\
\hline 1,8 & 2 & & 2,925 & 10,10 & 0.021 & 0.119 & 0.098 & 0.457 & 82 \\
\hline 1,10 & 4 & & 2,840 & 2,00 & 0.021 & 0.105 & 0.084 & 0.447 & 80 \\
\hline 1,14 & 8 & & 2,670 & 10,45 & 0.026 & 0.114 & 0.088 & 0.407 & 77 \\
\hline 1,17 & 11 & & 2,660 & 12,40 & 0.018 & 0.116 & 0.098 & 0.433 & 84 \\
\hline 1,20 & 14 & & 2,590 & 10,30 & 0.019 & 0.115 & 0.096 & 0.384 & 83 \\
\hline 1,22 & 16 & & 2,530 & 10,15 & 0.025 & 0.114 & 0.089 & 0.438 & 78 \\
\hline 1,25 & 19 & & 2,610 & 12,30 & 0.018 & 0.101 & 0.083 & 0.428 & 82 \\
\hline 1,28 & 22 & & 2,570 & 10,00 & 0.019 & 0.103 & 0.084 & 0.438 & 82 \\
\hline 1,31 & 25 & & 2,740 & 11,35 & 0.021 & 0.108 & 0.087 & 0.414 & 81 \\
\hline \multirow[t]{7}{*}{3,12} & \multirow[t]{7}{*}{1} & \multirow[t]{15}{*}{47 白 $\delta$} & \multirow[t]{7}{*}{2,130} & 10,40 & 0.022 & 0.133 & 0.111 & 0.484 & 83 \\
\hline & & & & 11,45 & 0.021 & 0.130 & 0.109 & 0.462 & 84 \\
\hline & & & & 1,00 & 0.023 & 0.129 & 0.106 & 0.472 & 82 \\
\hline & & & & 2,00 & 0.022 & 0.127 & 0.105 & 0.487 & 83 \\
\hline & & & & 3,00 & 0.024 & 0.126 & 0.102 & 0.456 & 81 \\
\hline & & & & 4,00 & 0.021 & 0.124 & 0.103 & 0.457 & 83 \\
\hline & & & & $5, \quad 00$ & 0.021 & 0.126 & 0.105 & 0.448 & 83 \\
\hline 3,13 & 2 & & 2,130 & 2,15 & 0.019 & 0.121 & 0.102 & 0.516 & 84 \\
\hline 3,16 & 5 & & 2,050 & 12,00 & 0.025 & 0.130 & 0.105 & 0.452 & 81 \\
\hline 3,18 & 7 & & 2,080 & 1,00 & 0.022 & 0.127 & 0.105 & 0.432 & 83 \\
\hline 3,20 & 9 & & 2,060 & 2,00 & 0.024 & 0.119 & 0.095 & 0.410 & 80 \\
\hline 3,23 & 12 & & 2,175 & 1,00 & 0.016 & 0.117 & 0.101 & 0.412 & 81 \\
\hline 3,25 & 14 & & 2,040 & 1,00 & 0.022 & 0.121 & 0.099 & 0.461 & 82 \\
\hline 3,28 & 17 & & 2,145 & 1,00 & 0.022 & 0.122 & 0.100 & 0.394 & 83 \\
\hline 3,31 & 20 & & 2,040 & 1,00 & 0.020 & 0.126 & 0.106 & 0.394 & 84 \\
\hline
\end{tabular}

第一圖 健康家鬼血液瓦斯 (47號)

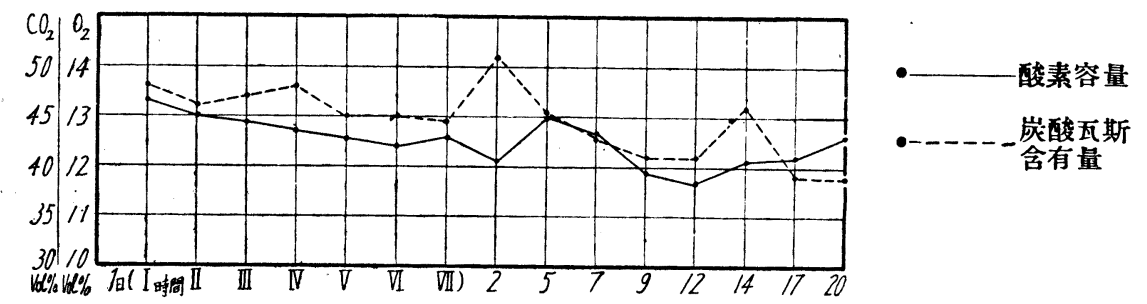


定スルコト少ク種々，影製タ蒙り易ク其含有量モ比較的動搖シ易キガ如シ。余ノ實驗 ニア・リテハ實驗第 1 日ニアリテハ大ナル動搖フ示スコト少ナキモ第 1 回測定時ヨリ漱 次增加シ酸素容量, 增減ト相反シ $2-3$ 時間目二最高トナリ更二幾分低下ォ示シ $5-6$ 時間ニシテ最初ノ狀態二復歸スルモノ、如シ。第 2 日目ニ八相當著明ノ增加テ來シ更 二第 2 週ニ於テモ相常ノ增加テ來セルモノ多ク其ノ後八輕度ノ動搖キ示シッ、略く一 定/値尹保持セルガ如シ。試驗中試獸ニ對シテハ常二充分ノ注意き以テ觀察セルモ採 血時二身體ノ運動キ焦シタルモノナク一般狀態二對シテ八實驗 2 日以後殊二食欲ノ減 退甚シク䉆二體重ノ減少著明ナルモノアリ。爾後日チ逐フテ元氣恢復シ食欲雽重等モ

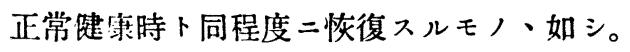

實驗第 1 日及ビ第 2 逼二於ケル家鬼動脈血酸素容量 減少㕸二炭酸瓦斯含有量ノ增 加ハ如何ナル理由二基クモノナルカ。余八實驗第 1 日二於テ動物テ早朝空腹時ニ之ョ 固定器二背位二固定シ 1 日中毫モ食趾 給スルコトナク數時間ノ長キ二瓦り其血液瓦

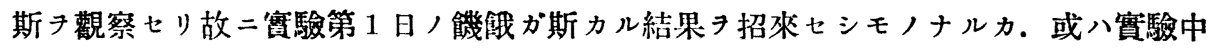

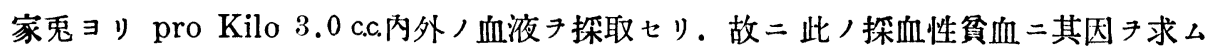
ベキモノナルカ。Hasselbach 氏八餧稣第 1 日二於ケル肺胞內炭酸瓦斯二著變キ認メ ズ第 2 日二藷明ノ減少チ認メタリ。然レドモ Evans 氏八動物ガ何等カノ理由ニテ食

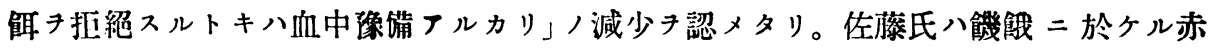
血球，變化于研究シ赤血球八約 2 週目二減少シ後增加スト云へリ。大森氏八家鬼二於

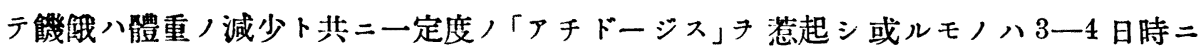
第2日ニ「アチドージス」ナ來スト云へリ。實驗的貧血二關シテハ楠氏ハ出血後ノ貧血 二際シテハ血液, 荻酸瓦斯含有量及ビ其/攝取能力モ共二減退七ルモ,ナリト㛵七

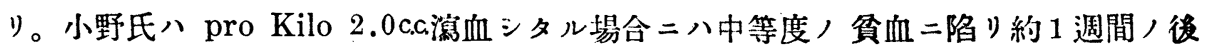
ニ至りテ殆ド恢復期赤血球增多キ經過スル事ナク舊二復シ pro Kilo 5.0c.c. 演血ノ場

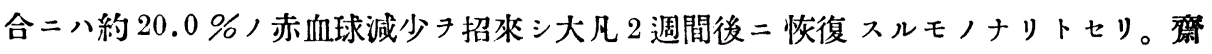
藤氏八家兔二就テ pro Kilo 10.0c.c 採血二於テ採血，翌日二於テ血中應错アルカリ量 減少シ第 3 日以後 5 日迄八漱次增加スルチ認メタリ。Tatum 氏ハ直二減少シテ數時間 二恢復スルキ見タリ。然レドモ佐脉氏八健康家鬼體重 pro Kilo 2.0c.c. 内外キ一時二 採血シタル場合其翌日該家鬼/動脈血酸素總容量及ビ炭酸瓦斯含有量ガ何レモ探血前 ノ值二略了相等シキ事キ認メ大本氏モ多量出血二反シ每日少量ヅ、(pro Kilo 2.0一 $6.0)$ 出血七シメタル亞急性出血性贫血二於テ八採血後血漿炭酸瓦斯含有量八第 1 日第 2 日中何等ノ變化モ認メ難シト云へリ。大森氏ハ急性貧血二際シテハ失血後 30 分二 
テ既ニ「アチドージス」フ起シ常體二復歸スルハ 24 時間以內ニシテ數回繰り返シテ採

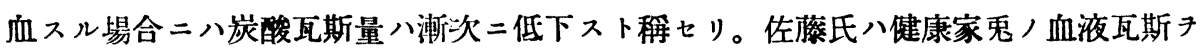
研究シ血液瓦斯八試獸, 固定方法及ビ採血方法等ニョリテ影掣七ラルベキコトテ記セ リ。泫二於テ上記ノ諸交獻き綜合シ前述セル健康家鬼動脈血液瓦斯含有量，變化八單

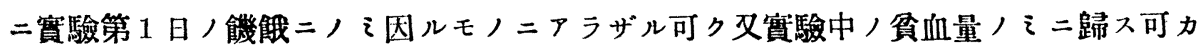
ラズ。恐ラク實驗第 1 日中ノ絕食竝二採血量，影製／他二長時二瓦ル背位固定及ビ殊 二頻包ノ心臟穿刺衍等, 作用ガ如何二有害且强力二作用スルカチ示スモノナリト信 ズ。此ノ如クニシテ家兔八其ノ瓦斯代謝二何等カノ障碍き來シ血液炭酸瓦斯含有量， 增加 來シ。血中遊離炭酸, 增加 來シ從テ血液酸素容量モ亦減少シタルモノナルべ シ。其ノ後家兔ガ其哀弱ヨリ一旦脫却シ得ル時二當りテハ其ノ瓦斯代謝モ正常二復シ 血液瓦斯モ漱次常態二移行スルモ, 解釋スルキ至常ナリト信ズ。

\section{第二節＼cjkstart異種性大動脈內被細胞成分注入ノ場合}

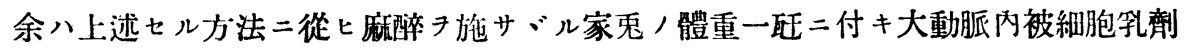

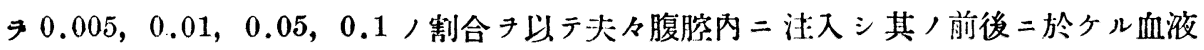
瓦斯測定セり。

第 二 表

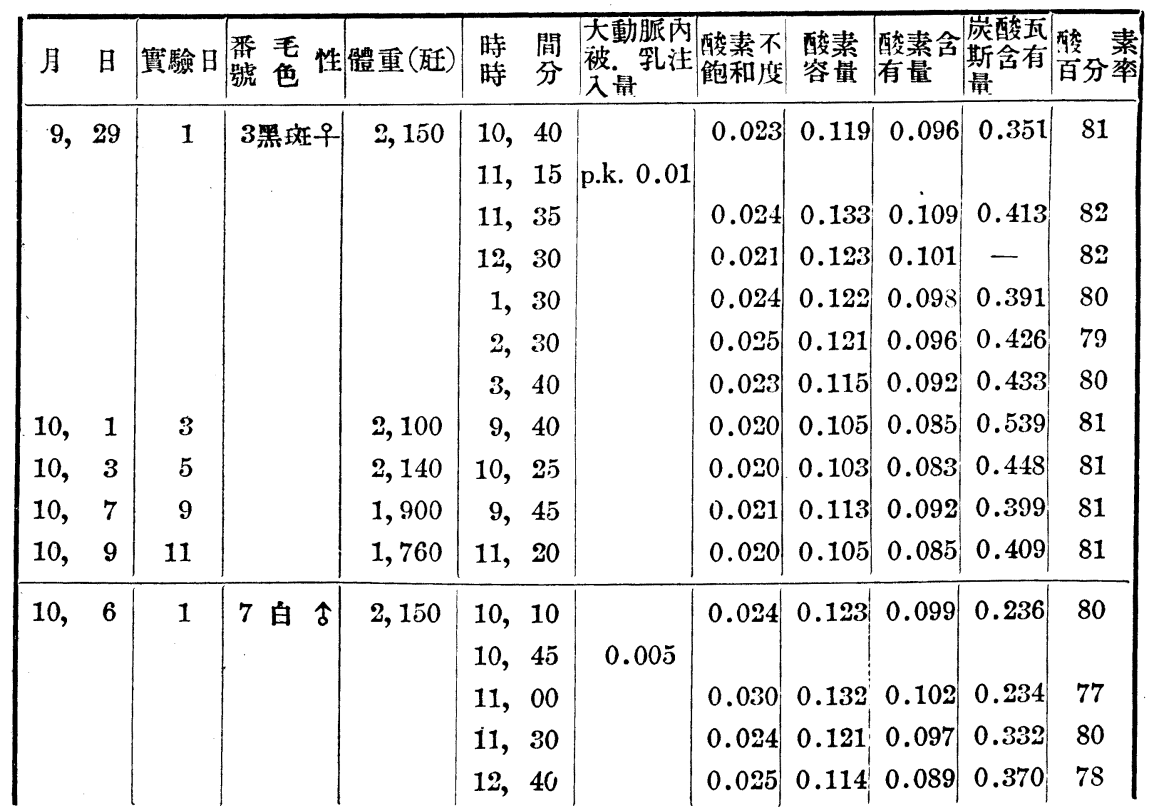




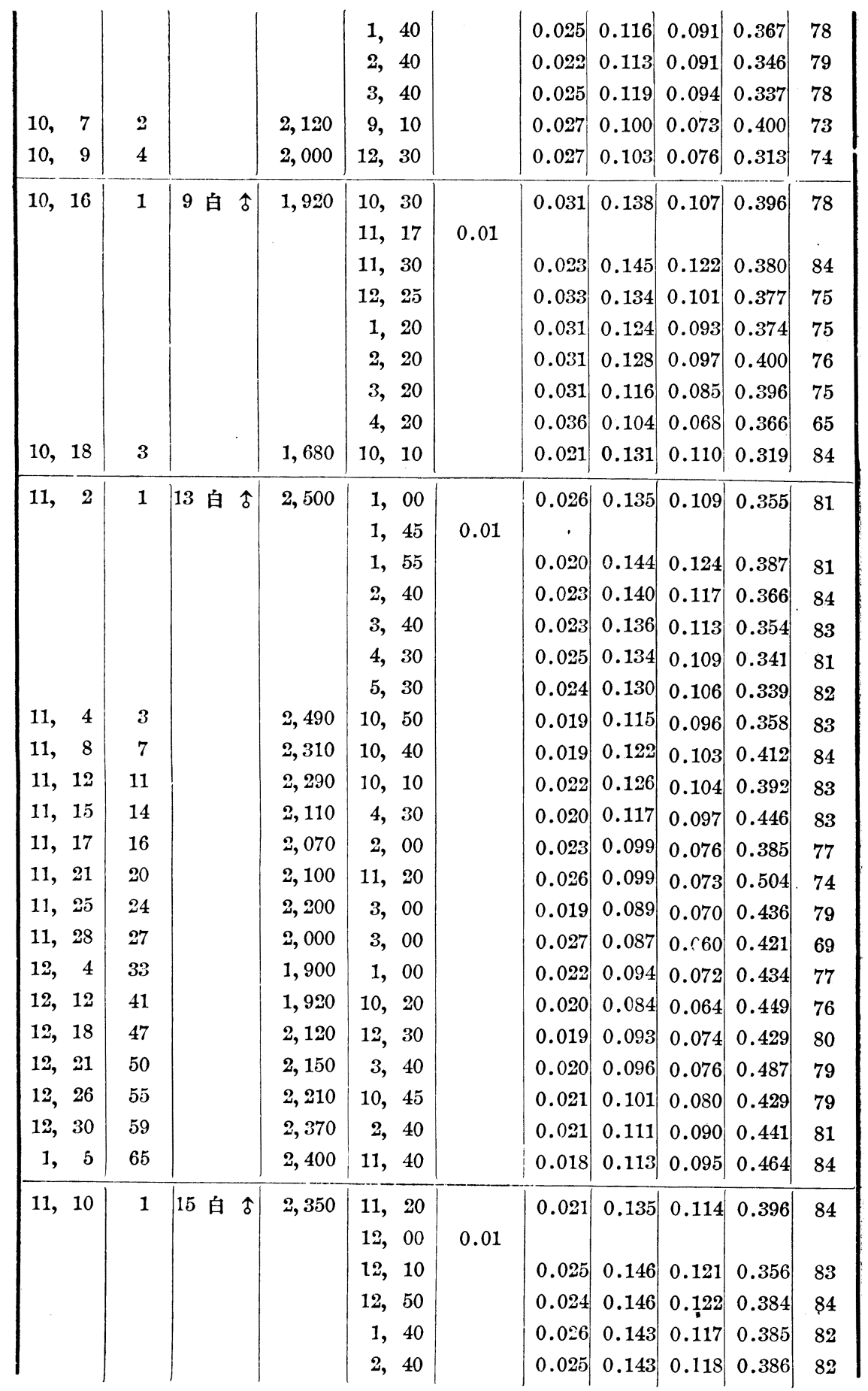




\begin{tabular}{|c|c|c|c|c|c|c|c|c|c|c|}
\hline & & & & 3,40 & & $|0.025|$ & $|0.144|$ & $|0.121|$ & $0.383 \mid$ & 84 \\
\hline & & & & 4,40 & & 0.026 & 0.140 & 0.114 & 0.387 & 81 \\
\hline 11,11 & 2 & & 2,200 & 10,30 & & 0.027 & 0.131 & 0.104 & 0.361 & 79 \\
\hline 11,13 & 4 & & 2,210 & 10,00 & & 0.020 & 0.141 & 0.121 & 0.379 & 86 \\
\hline 11,17 & 8 & & 2,210 & 11,50 & & 0.028 & 0.123 & 0.095 & 0.408 & 77 \\
\hline 11,19 & 10 & & 2,240 & 10,00 & & 0.017 & 0.105 & 0.088 & 0.440 & 84 \\
\hline 11,21 & 12 & & 2,430 & 5,00 & & 0.027 & 0.103 & 0.076 & 0.461 & 74 \\
\hline 11,25 & 16 & & 2,420 & 1,00 & & 0.024 & 0.107 & 0.083 & 0.435 & 78 \\
\hline 11,28 & 19 & & 2,420 & 1,00 & & 0.025 & 0.111 & 0.086 & 0.447 & 78 \\
\hline 12,4 & 25 & & 2,240 & 10,45 & & 0.015 & 0.106 & 0.091 & 0.428 & 86 \\
\hline 12,7 & 28 & & 2,290 & 2,30 & & 0.021 & 0.099 & 0.078 & 0.434 & 79 \\
\hline 12,9 & 30 & & 2,340 & 2,55 & & 0.021 & 0.086 & 0.065 & 0.466 & 77 \\
\hline 12,14 & 35 & & 2,400 & 2,55 & & 0.027 & 0.101 & 0.074 & 0.429 & 73 \\
\hline 12,19 & 40 & & 2,350 & 2,00 & & 0.020 & 0.090 & 0.070 & 0.434 & 78 \\
\hline 12,22 & 43 & & 2,550 & 2,30 & & 0.018 & 0.096 & 0.078 & 0.440 & 81 \\
\hline 12,26 & 47 & & 2,600 & 1,30 & & 0.023 & 0.104 & 0.081 & 0.461 & 78 \\
\hline 12,30 & 51 & & 2,550 & 1,50 & & 0.024 & 0.114 & 0.090 & 0.432 & 79 \\
\hline $1, \quad 5$ & 57 & & 2,640 & 1,50 & & 0.022 & 0.114 & 0.092 & 0.511 & 81 \\
\hline 1,10 & 62 & & 2,670 & 2,45 & & 0.024 & 0.115 & 0.091 & 0.481 & 79 \\
\hline 1,15 & 67 & & 2,720 & 2,25 & & $|0.020|$ & 0.109 & $\mid 0.089$ & 0.452 & 82 \\
\hline 11,16 & 1 & $\mid 17$ 白 $\hat{\delta}$ & 2,080 & $\begin{array}{ll}11, & 00 \\
11, & 45\end{array}$ & 0.01 & 0.026 & 0.123 & 0.097 & 0.481 & 79 \\
\hline & & & & 12,00 & & 0.026 & 0.132 & 0.106 & 0.480 & 80 \\
\hline & & & & 12,40 & & 0.026 & 0.133 & 0.107 & 0.471 & 80 \\
\hline & & & & 1,30 & & 0.022 & 0.131 & 0.109 & 0.445 & 83 \\
\hline & & & & 2,30 & & 0.024 & 0.134 & 0.110 & 0.434 & 82 \\
\hline & & & & 3,30 & & 0.023 & 0.130 & 0.107 & 0.419 & 82 \\
\hline & & & & 4,30 & & 0.027 & 0.130 & 0.103 & 0.434 & 79 \\
\hline 11,17 & 2 & & 1,930 & 9,50 & & 0.022 & 0.125 & 0.103 & 0.475 & 82 \\
\hline 11,19 & 4 & & 2,080 & 3,00 & & 0.021 & 0.123 & 0.102 & 0.427 & 83 \\
\hline 11,23 & 8 & & 1,950 & 11,00 & & 0.026 & 0.117 & 0.091 & 0.438 & 78 \\
\hline 11,25 & 10 & & 2,100 & 4,00 & & 0.023 & 0.122 & 0.099 & 0.455 & 81 \\
\hline 11,28 & 13 & & 1,960 & 4,00 & & 0.026 & 0.122 & 0.096 & 0.438 & 79 \\
\hline 11,22 & 1 & 19 白 $\hat{8}$ & 2,300 & $\begin{array}{ll}10, & 00 \\
10, & 50\end{array}$ & 0.005 & & 0.160 & 0.138 & 0.371 & 86 \\
\hline & & & & 11,05 & & 0.027 & 0.165 & 0.138 & 0.388 & 84 \\
\hline & & & & 12,05 & & 0.031 & 0.157 & 0.126 & 0.397 & 80 \\
\hline & & & & 1,00 & & 0.028 & 0.156 & 0.128 & 0.404 & 82 \\
\hline & & & & 2,00 & & 0.028 & 0.164 & 0.136 & 0.394 & 83 \\
\hline & & & & 3,00 & & 0.034 & 0.155 & 0.121 & 0.348 & 78 \\
\hline & & & & 4,00 & & 0.030 & 0.156 & 0.126 & 0.379 & 81 \\
\hline 11,23 & 2 & & 2,200 & 10,05 & & 0.030 & 0.141 & 0.111 & 0.383 & 79 \\
\hline
\end{tabular}




\begin{tabular}{|c|c|c|c|c|c|c|c|c|c|c|}
\hline 11,25 & 4 & & 2,200 & 12,00 & & 0.023 & 0.148 & 0.119 & 0.382 & 84 \\
\hline 11,28 & 7 & & 2,300 & 5,00 & & 0.025 & 0.139 & 0.114 & 0.378 & 82 \\
\hline $12, \quad 5$ & 14 & & 2,110 & 2,00 & & 0.029 & 0.121 & 0.092 & 0.435 & 77 \\
\hline 12,12 & 21 & & 2,075 & 4,35 & & 0.026 & 0.115 & 0.089 & 0.454 & 77 \\
\hline 12,15 & 24 & & 2,120 & 1,55 & & 0.020 & 0.117 & 0.097 & 0.407 & 83 \\
\hline $12, \quad 19$ & 28 & & 2,210 & 3,00 & & 0.024 & 0.105 & 0.081 & 0.400 & 77 \\
\hline 12,21 & 31 & & 2,090 & 2,30 & & 0.022 & 0.115 & 0.093 & 0.440 & 81 \\
\hline 12,25 & 35 & & 2,240 & 4,05 & & 0.022 & 0.122 & 0.100 & 0.452 & 82 \\
\hline 12,30 & 40 & & 2,200 & 11,45 & & 0.025 & 0.125 & 0.100 & 0.407 & 80 \\
\hline $1, \quad 5$ & 45 & & 2,220 & 12,35 & & 0.021 & 0.122 & 0.101 & 0.484 & 83 \\
\hline 1,10 & 50 & & 2,180 & 3,40 & & 0.025 & 0.139 & 0.114 & 0.470 & 82 \\
\hline $1, \quad 5$ & 55 & & 2,190 & 9,50 & & 0.018 & 0.139 & 0.121 & 0.474 & 87 \\
\hline 1,18 & 58 & & 2,200 & 10,30 & & 0.020 & 0.128 & 0.108 & 0.450 & 84 \\
\hline 1,21 & 61 & & 2,230 & 3,30 & & 0.018 & 0.136 & 0.118 & 0.428 & 87 \\
\hline 1,23 & 63 & & 2,140 & 11,40 & & 0.024 & 0.133 & 0.109 & 0.492 & 82 \\
\hline 1,26 & 66 & & 2,180 & 3,50 & & 0.018 & 0.142 & 0.124 & 0.472 & 87 \\
\hline 1,28 & 68 & & 2,145 & 12,10 & & 0.023 & 0.141 & 0.118 & 0.428 & 84 \\
\hline 11,29 & 1 & 43 白 $\hat{\delta} \mid$ & 2,570 & 2,40 & & 0.019 & 0.127 & 0.108 & 0.348 & 85 \\
\hline & & & & $\begin{array}{ll}3, & 15 \\
3, & 30\end{array}$ & 0.01 & 0.018 & 0.131 & 0.113 & 0.403 & 86 \\
\hline & & & & 4,30 & & 0.019 & 0.120 & 0.101 & 0.382 & 84 \\
\hline & & & & 5,30 & & 0.019 & 0.118 & 0.099 & 0.373 & 84 \\
\hline & & & & 6,30 & & 0.019 & 0.121 & 0.102 & 0.378 & 84 \\
\hline 11,30 & 2 & & 2,450 & 4,40 & & 0.020 & 0.120 & 0.100 & 0.425 & 83 \\
\hline $12, \quad 5$ & 7 & & 2,480 & 11,00 & & 0.015 & 0.122 & 0.107 & 0.337 & 88 \\
\hline 12,10 & 12 & & 2,480 & 2,50 & & 0.021 & 0.114 & 0.093 & 0.455 & 82 \\
\hline 12,15 & 17 & & 2,320 & 12,40 & & 0.023 & 0.122 & 0.099 & 0.405 & 81 \\
\hline 12,19 & 21 & & 2,490 & 4,00 & & 0.024 & 0.110 & 0.086 & 0.388 & 78 \\
\hline 12,23 & 24 & & 2,500 & 3,30 & & 0.017 & 0.112 & 0.095 & 0.425 & 84 \\
\hline 12,26 & 27 & & 2,610 & 1,50 & & 0.023 & 0.108 & 0.085 & 0.406 & 79 \\
\hline 12,31 & 32 & & 2,640 & 2,45 & & 0.022 & 0.128 & 0.106 & 0.384 & 83 \\
\hline 1,6 & 38 & & 2,680 & 2,50 & & 0.018 & 0.126 & 0.108 & 0.452 & 86 \\
\hline 1,12 & 44 & & 2,480 & 10,15 & & 0.024 & 0.147 & 0.123 & 0.482 & 84 \\
\hline 1,15 & 47 & & 2,690 & 11,10 & & 0.023 & 0.132 & 0.109 & 0.428 & 83 \\
\hline 1,18 & 50 & & 2,640 & 12,30 & & 0.024 & 0.136 & 0.112 & 0.440 & 82 \\
\hline 1,21 & 53 & & 2,685 & 11,00 & & 0.020 & 0.124 & 0.104 & 0.412 & 84 \\
\hline 1,23 & 55 & & 2,640 & 10,30 & & 0.018 & 0.132 & 0.114 & 0.441 & 86 \\
\hline 1,26 & 58 & & 2,650 & 10,30 & & 0.016 & 0.131 & 0.115 & 0.402 & 88 \\
\hline 1,28 & 60 & & 2,620 & 10,15 & & 0.020 & 0.136 & 0.116 & 0.372 & 85 \\
\hline $2, \quad 1$ & 63 & & 2,575 & 10,50 & & 0.021 & 0.136 & 0.115 & 0.377 & 85 \\
\hline $2, \quad 4$ & 66 & & 2,620 & 1,20 & & 0.023 & 0.138 & 0.115 & 0.468 & 83 \\
\hline 11,30 & 1. & 44 白 \{ & 2,4 & & & & 0.11 & 0.0 & $0.354 \mid$ & 82 \\
\hline
\end{tabular}




\begin{tabular}{|c|c|c|c|c|c|c|c|c|c|}
\hline \multirow{7}{*}{ 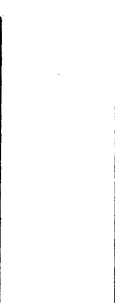 } & & & 10,15 & 0.01 & & & & & \\
\hline & & & 10,30 & & 0.022 & 0.124 & 0.102 & 0.395 & 82 \\
\hline & & & 11,20 & & 0.023 & 0.121 & 0.098 & 0.380 & 81 \\
\hline & & & 12,30 & & 0.021 & 0.119 & 0.098 & 0.388 & 82 \\
\hline & & & 1,30 & & 0.020 & 0.117 & 0.097 & 0.372 & 83 \\
\hline & & & 2,30 & & 0.018 & 0.112 & 0.094 & 0.387 & 84 \\
\hline & & & 3,30 & & 0.021 & 0.118 & 0.097 & 0.401 & 82 \\
\hline $12, \quad 1$ & 2 & 2,300 & 10,00 & & 0.018 & 0.119 & 0.101 & 0.382 & 85 \\
\hline 12,4 & 5 & 2,230 & 3,00 & & 0.025 & 0.109 & 0.084 & 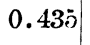 & 77 \\
\hline 12,11 & 12 & 2,360 & 3,30 & & 0.018 & 0.095 & 0.077 & 0.417 & 81 \\
\hline 12,15 & 16 & 2.250 & 3,15 & & 0.020 & 0.098 & 0.078 & 0.436 & 80 \\
\hline $12, \quad 19$ & 20 & 2,320 & 1,00 & & 0.020 & 0.100 & 0.080 & 0.417 & 80 \\
\hline 12,23 & 24 & 2,500 & 1,30 & & 0.019 & 0.093 & 0.074 & 0.416 & 80 \\
\hline 12,25 & 26 & 2,400 & 3,15 & & 0.022 & 0.107 & 0.085 & 0.442 & 79 \\
\hline 12,30 & 31 & 2,470 & 1,00 & & 0.024 & 0.105 & 0.081 & 0.442 & 77 \\
\hline $1, \quad 4$ & 36 & 2,430 & 11,20 & & 0.020 & 0.114 & 0.094 & 0.384 & 82 \\
\hline 1,7 & 39 & 2,450 & 9,35 & & 0.023 & 0.117 & 0.094 & 0.428 & 80 \\
\hline 1,14 & 46 & 2,320 & 3,00 & & 0.023 & 0.120 & 0.097 & 0.448 & 81 \\
\hline 1,17 & 49 & 2,320 & 3,30 & & 0.023 & 0.127 & 0.104 & 0.387 & 82 \\
\hline 1,21 & 53 & 2,300 & 2,00 & & 0.022 & 0.112 & 0.090 & 0.410 & 80 \\
\hline 1,23 & 55 & 2,290 & 1,40 & & 0.021 & 0.117 & 0.096 & 0.451 & 82 \\
\hline 1,26 & 58 & 2,230 & 12,00 & & 0.019 & 0.115 & 0.096 & 0.417 & 83 \\
\hline 1,29 & 61 & 2,300 & 11,10 & & 0.020 & 0.121 & 0.101 & 0.438 & 83 \\
\hline $2, \quad 1$ & 64 & 2,370 & 12,20 & & 0.023 & 0.118 & 0.095 & 0.443 & 81 \\
\hline $2, \quad 4$ & 67 & 2,480 & 1,45 & & 0.020 & 0.119 & 0.099 & 0.410 & 83 \\
\hline
\end{tabular}

第 二 圖

牛大動胍內被細胞乳劑注入 (pro kilo 0.01 (13號)

- - 酸素答量 D.- - - 炭酸瓦斯含有量

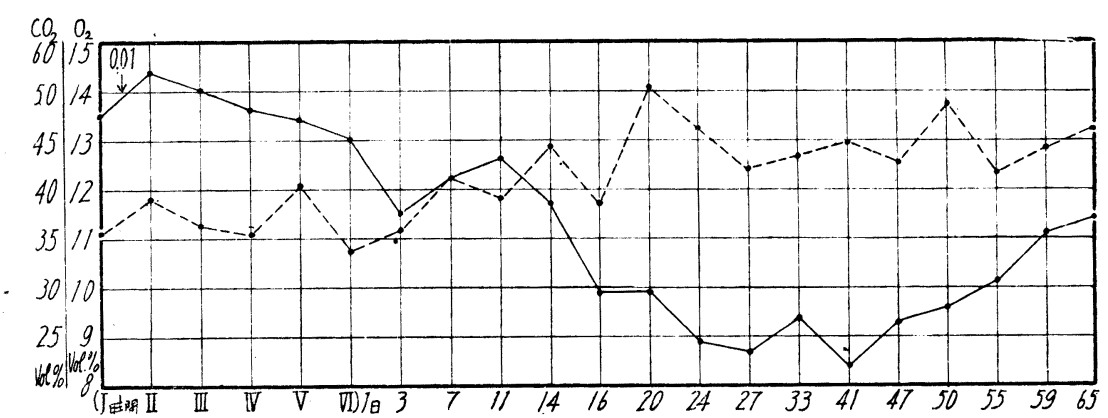

第一 適當刺戟量注入，場合 pro Kilo 0.01 于家鬼腹腔內二注入シテ其/前後二 於ケル家鬼動脈血，血液瓦斯 测定スル二第 2 表及ビ第 2 圖二明示セルガ如ク酸素容 
量八乳剂注入後二於テ常二一定ノ增加 來セり(No. 3, No. 13, No. 44 二於テハ輕度 さガラ 2-3 時間／持續的增加タ認メタリ)其，增加／度八著明ナラズ。極メテ僅少ナ レドモ總例二於テ認メラル、モノニシテ後節ニ於テ記載セントセル大量注入及ビ對照 實驗例二比シ著明ノ差アリ。郎チ對照實驗二於テハ注入後酸素容量/增加き來セシモ ノナシ.コレ等ノ事實ヨリ觀レバ酸素容量ノ增加ハ乳劑洼入ノ結果卜見做スキ得ベシ。 pro Kilo 0.005 注入，場合モ(第 2 表 No. 7) 前例同樣注入後酸素容量，增加 7 來七 上。何レノ場合モ酸素容量ハ其ノ後泝次減少スルモ其ノ程度八健康家鬼二比較シテ何 等著明ノ差異キ認メズ。第 2 日以後數週間ノ經過き觀ル二實驗第 2 日目ニハ相當著明 ノ減少き來シ更ニ一旦減少シ次デ渐次增加シ常態二復歸スルモノ、如クニテ其ノ變化 ノ狀態八健康家兔ノソレト略 ? 相一致七ルモ)、如 シ (第 1 表. 第 1 圖參照). 酸素不

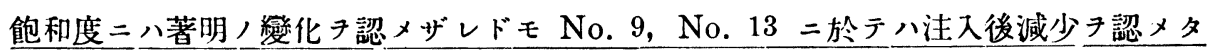
ルモ其/他ノ例二於テハ著變ナク時間，經過卜共二絒分增加キ認メタリ。從テ酸素含 有量八略了酸素容量二隨伴シテ變動スルガ如ク. 注入後第 1 回ノ測定二於テ稍 3 增加 ヨ示セルコト前述セル容量, 場合卜同樣ナリ。其ノ後整時ニシテ復歸シ更二第 2 日目

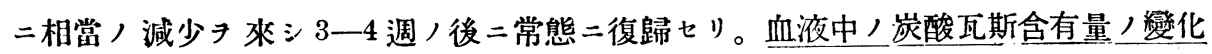
八乳剂注入後 10 乃至 20 分遲クモ 1 時間以内二酸素容量及ビ酸素含有量 /增加二伴七 輕度ナガラ減少尹來セルモノアリ(No. 3, No. 5, No. 7, No. 9, No. 15, No. 17)他 ，例二於テハ一旦增加尹來セル後減少キ來セルカ或八著明，變化認メザルモ，等ア

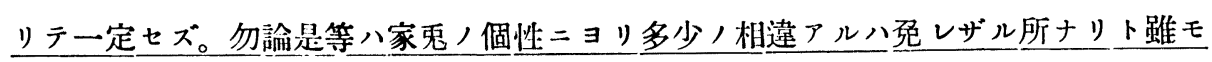
酸素容量增加時二減少七ル炭酸瓦斯八更二時間，經過二從七漸次增加シ更二數時間後 三減少三第 2 日以後八相當增加 來七ルモ/多シ。是等/變化八健康家鬼二於ヶルト 同樣實驗第 1 日，長時間／背位固定泣二頻包／心藏穿刺及ビ饑稣等ガ如何二强烈有害 二作用シタルャタ示スモノナリ。乳劑注入直後ノ炭酸瓦斯含有量ノ減少八酸素容量站 二酸素含有量, 增加二作つモノニシテ該乳劑洼入二依り瓦斯代謝元蕉キ來三酸素量增 加シ炭酸瓦斯含有量, 減少尹來七ルモノト訟明スルチ得ベシ。佐藤氏ハ肺藏細胞孚剂 ノ小量 pro Kilo 0.05 以下ヲ注入七ル二酸素含有量, 增加き認メズ肺臟細胞乳剂, 適當ナル刺戟量八佔逪二微少ナラント云へリ。余モ又大動脈內被細胞乳劑 pro Kilo 0.05 以上二於テ酸素含有量，增加キ認メズ(第二節參照)シテソレ以下，量二テ酸素 容量及ビ酸素含有量/增加子認メタリ。郎チ pro Kilo $0.005-0.01$ 八余ノ場合二於 テ八適賞刺戟量タルベク該量注入二於テハ瓦斯代謝キ元進セシメ得ベシ。一般狀態二

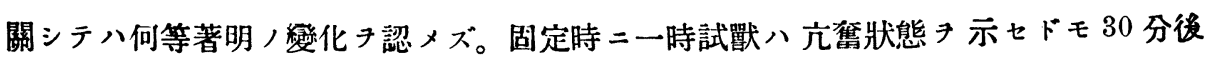




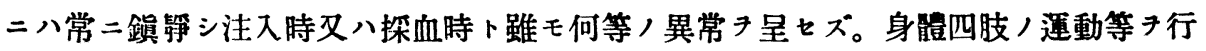
フコトナク特二呼吸狀態モ極メテ安靜ナリ。勿論 Cyanose ヨ來セルモノナシ。第 1 日ノ饑餓及ビ諸操作等二因リ體重ハ一眭減少七ルモ其ノ後渐次常態二復歸七ルモノ多 シ。

第二. 大量注入 場合余八更二大動脈內被細胞乳矵ノ大量 (pro Kilo $0.05-0.1)$ チ 注入シ其/前後ニ於ヶル血液瓦斯ヨ測定セリ。pro Kilo $0.05-0.1$ ノ注入ニヨリ酸 素容量八第 3 表. 第 3 圖及ビ第 4 圖二明示セルガ如ク注入直後二於テモ增加テ示スコ トナク直二減少シ 2 -3 時間後其ノ極二達シス八漸次減少ヲ來スモ，等アレドモ一般 二一時減少セルモ其/後輕度/恢復き來シ. 實驗第 2 日二於テハ pro Kilo 0.05 注入 ノ場合八前日ヨり幾分增加來シ. pro Kilo 0.1 ニテハ減少シ更二數日後一旦減少 シ漸次恢復二向フ。然レドモ適當刺戟量ノ場合ヨリ恢復二镸期間キ要スルモノ多シ。

第 $\quad$ 表

\begin{tabular}{|c|c|c|c|c|c|c|c|c|c|c|c|}
\hline 月 日 & 賽驗日 & 號 色 & 體重(䣶) & $\begin{array}{l}\text { 時 } \\
\text { 時 }\end{array}$ & 闆 & 注入量 & 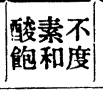 & $\begin{array}{l}\text { 酸素 } \\
\text { 容 } \\
\end{array}$ & 酸素含 & $\mid \begin{array}{l}\text { 岸酸瓦 } \\
\text { 斯含有 } \\
\text { 量 }\end{array}$ & 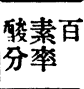 \\
\hline \multirow[t]{7}{*}{10,23} & 1 & 11白斑우 & 1,730 & & 50 & & 0.015 & 0.134 & 0.119 & $|0.340|$ & 89 \\
\hline & & & & & & 0.05 & 0.023 & 0.136 & 0.113 & 0.377 & 83 \\
\hline & & & & 12 & & & 0.027 & 0.122 & 0.095 & 0.384 & 78 \\
\hline & & & & 1, & 15 & & 0.026 & 0.118 & 0.032 & 0.373 & 79 \\
\hline & & & & 2 & 20 & & 0.028 & 0.118 & 0.090 & 0.389 & 76 \\
\hline & & & & 3 & 30 & & 0.025 & 0.118 & 0.093 & 0.369 & 79 \\
\hline & & & & 4, & 30 & & 0.028 & 0.109 & 0.081 & 0.303 & 74 \\
\hline 10,24 & 2 & & 1,630 & 9 & 55 & & 0.014 & 0.120 & 0.106 & 0.403 & 88 \\
\hline 10,28 & 6 & & 1,660 & 1, & 00 & & 0.026 & 0.119 & 0.093 & 0.337 & 85 \\
\hline 11,4 & I3 & & 1,590 & 11, & 30 & & 0.025 & 0.106 & 0.081 & 0.389 & 75 \\
\hline 11,9 & 18 & & 1,450 & 10 & 10 & & 0.018 & 0.119 & 0.101 & 0.342 & 85 \\
\hline 11,17 & 26 & & 1,490 & 4 , & 30 & & 0.022 & 0.091 & 0.069 & 0.383 & 76 \\
\hline 11,23 & 32 & & 1,430 & 3 & 00 & & 0.026 & 0.077 & 0.051 & 0.450 & 66 \\
\hline 11,26 & 35 & & 1,520 & 4 & 00 & & 0.019 & 0.073 & 0.054 & 0.428 & 74 \\
\hline 11,29 & 38 & & 1,480 & 10 & 00 & & 0.021 & $0.07 \mathrm{~S}$ & 0.057 & 0.401 & 73 \\
\hline 12,10 & 49 & & 1,510 & 9 & 30 & & 0.018 & 0.092 & 0.074 & 0.400 & 80 \\
\hline 12,15 & 54 & & 1,540 & 4 , & 10 & & 0.020 & 0.082 & 0.062 & 0.472 & 76 \\
\hline 12,19 & 58 & & 1,620 & 10 & 30 & & 0.021 & 0.082 & 0.061 & 0.364 & 74 \\
\hline 12,22 & 61 & & 1,580 & 10 & 15 & & 0.021 & 0.087 & 0.063 & 0.393 & 72 \\
\hline 12,26 & 65 & & 1,740 & 9 , & 50 & & 0.019 & 0.092 & 0.073 & 0.415 & 79 \\
\hline 12,31 & 70 & & 1,780 & 10 & 30 & & 0.021 & 0.113 & 0.092 & 0.412 & 81 \\
\hline 1,6 & 76 & & 1,800 & 11, & 15 & & 0.025 & 0.113 & 0.088 & 0.418 & 78 \\
\hline
\end{tabular}




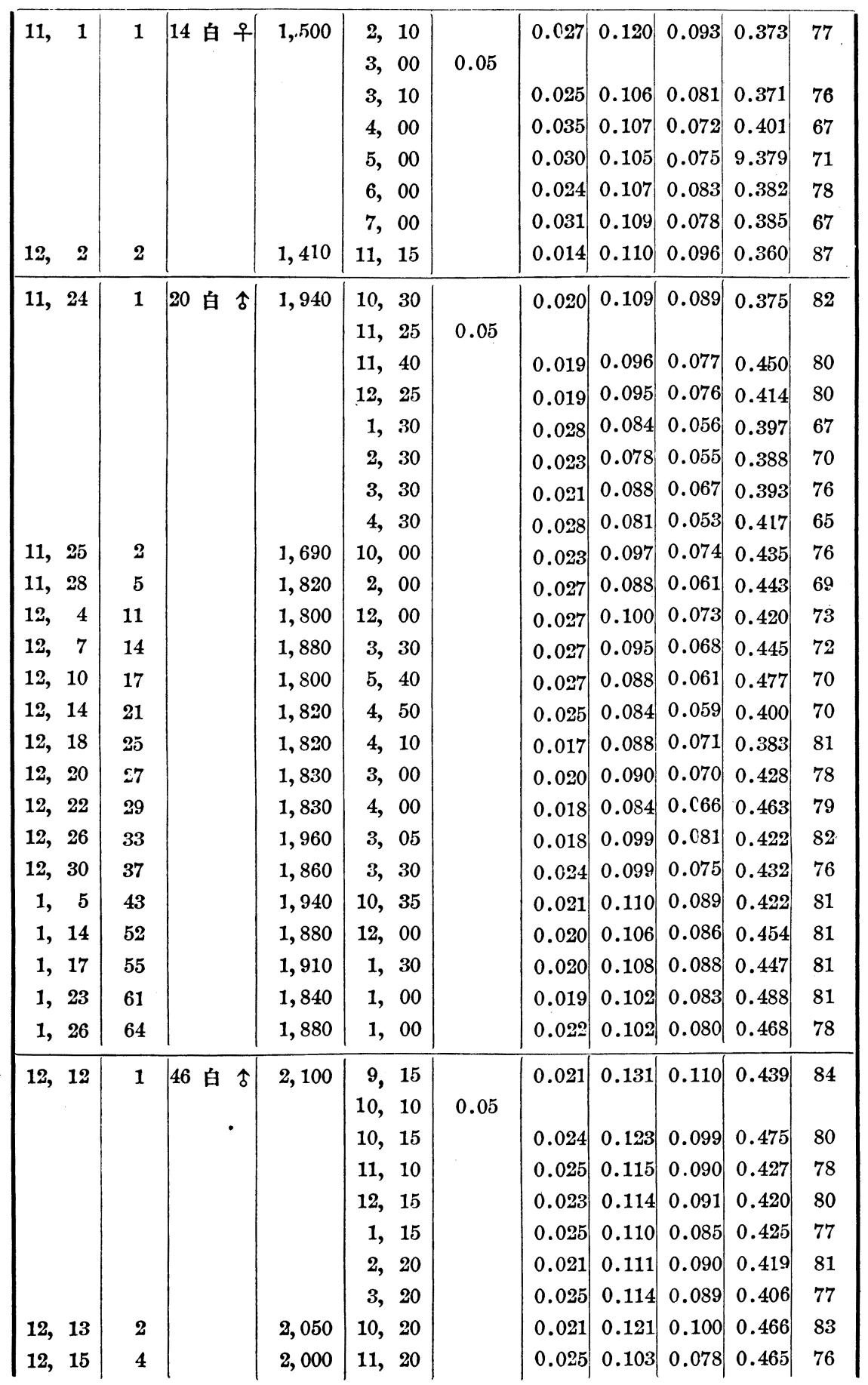




\begin{tabular}{|c|c|c|c|c|c|c|c|c|}
\hline 12,18 & 7 & 2,110 & 10,30 & 0.019 & 0.097 & 0.078 & 0.464 & 80 \\
\hline 12,21 & 10 & 2,100 & 10,45 & 0.020 & 0.094 & 0.074 & $0.45 t$ & 79 \\
\hline 12,25 & 14 & 2,250 & 1,15 & 0.019 & 0.092 & 0.073 & 0.458 & 79 \\
\hline 12,27 & 16 & 2,210 & $1, \cdot 50$ & 0.021 & 0.102 & 0.081 & 0.466 & 79 \\
\hline 12,31 & 20 & 2,130 & 11,20 & 0.023 & 0.096 & 0.073 & 0.490 & 76 \\
\hline 1,6 & 26 & 2,240 & 10,00 & 0.019 & 0.101 & 0.082 & 0.457 & 81 \\
\hline 1,12 & 32 & $\mathbf{2}, 090$ & 11,25 & 0.023 & 0.107 & 0.084 & 0.531 & 79 \\
\hline 1,14 & 34 & 2,085 & 1,00 & 0.020 & 0.110 & 0.090 & 0.496 & 82 \\
\hline 1,17 & 37 & 2,140 & 4,00 & 0.021 & 0.110 & 0.089 & 0.481 & 81 \\
\hline 1,20 & 40 & 2,140 & 4,10 & 0.021 & 0.108 & 0.087 & 0.497 & 80 \\
\hline 1,22 & 42 & 2,160 & 1,35 & 0.020 & 0.094 & 0.074 & 0.505 & 79 \\
\hline 1, 26 & 46 & 2,180 & 2,00 & 0.023 & 0.102 & 0.079 & 0.553 & 77 \\
\hline 1,28 & 48 & 2,130 & 3,50 & 0.021 & 0.104 & 0.083 & 0.462 & 80 \\
\hline 1,31 & 51 & 2,315 & 2,25 & 0.020 & 0.098 & 0.078 & 0.431 & 80 \\
\hline $2, \quad 3$ & 54 & 2,150 & 2,45 & 0.018 & 0.107 & 0.089 & 0.447 & 83 \\
\hline 2,6 & 57 & 2,240 & 4,45 & 0.023 & 0.099 & 0.076 & 0.479 & 79 \\
\hline 2, 9 & 60 & 2,230 & 4,50 & 0.022 & 0.096 & 0.074 & 0.449 & 77 \\
\hline 2,12 & 63 & 2,265 & 4,40 & 0.020 & 0.098 & 0.078 & 0.440 & 80 \\
\hline
\end{tabular}

牛大動脈內被細胞乳劑注入 (pro kilo 0.05) (20號)

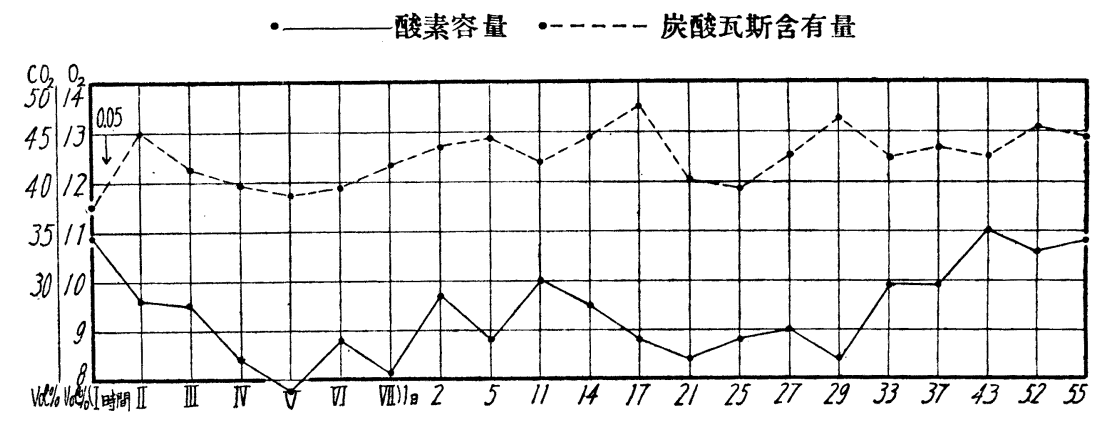

第四表

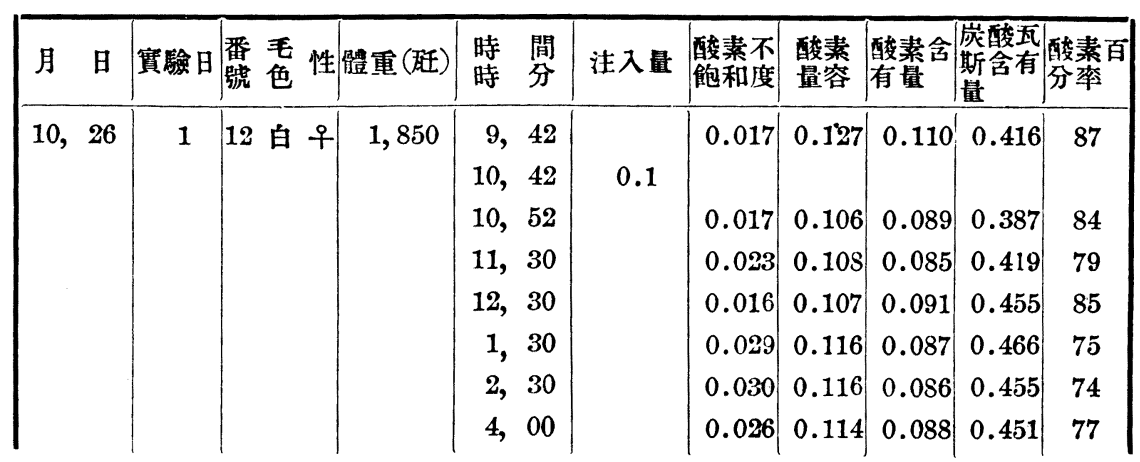




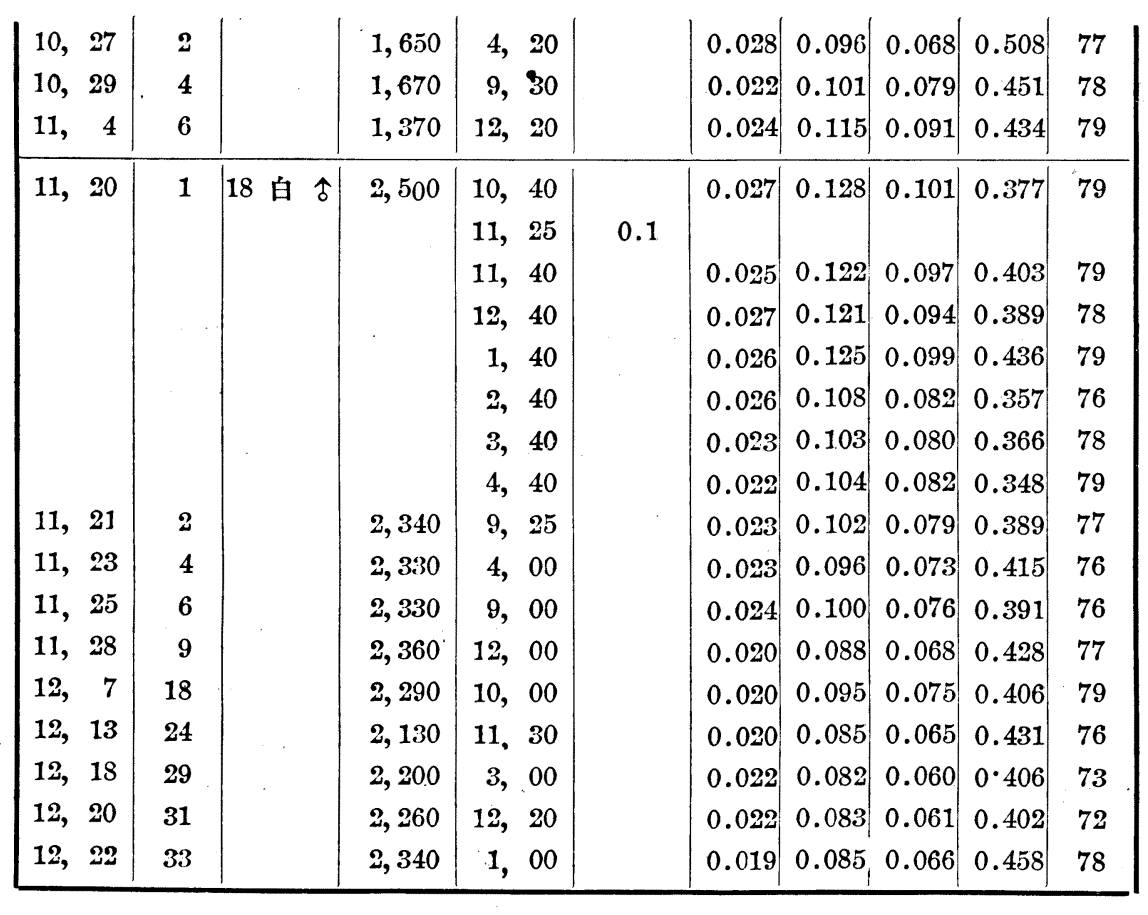

第四圆

牛大動脈內被細胞乳劑注入 (pro kilo 0.1) (12號)

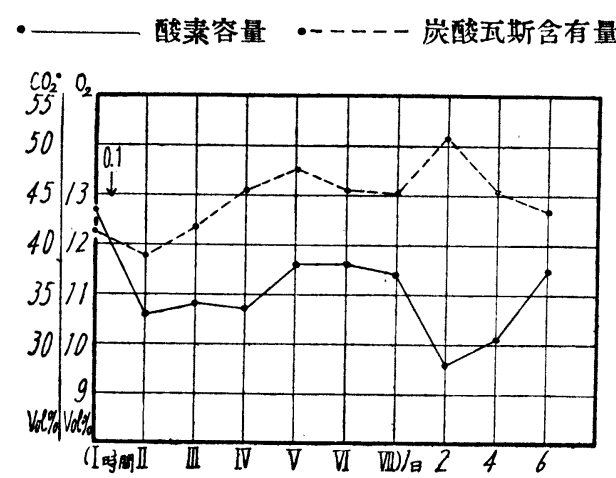

酸素不飽和度二著明ノ戀化き認メズ。從テ酸素含有量モ酸素容量二隨伴シテ略々同一

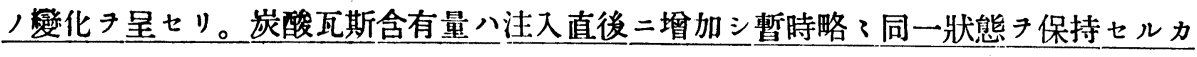
或ハ渪次減少セリ。第 2 日目二八著明ノ增加き來セルモノ多ク其ノ後八酸素量卜反對

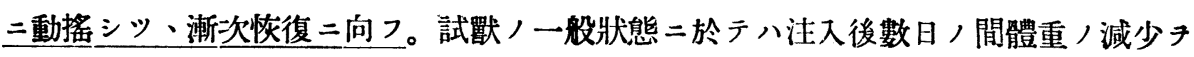
認ムル外何等著明!禁化き認メズ。

第一. 第三ヨ觀ルニ大動脈內被細胞乳劑/適當量注入，揚合二八血液酸素容量竝二 
酸素含有量ハ一時的ノ增加き來シ同時二炭酸瓦斯含有量八一時的ノ減少尹來ス，

大量注入, 場合二八血液酸素容量站二含有量/減少卜同時二㘸酸瓦斯含有量，增加 チ來ス。

\section{第三節 對照試驗}

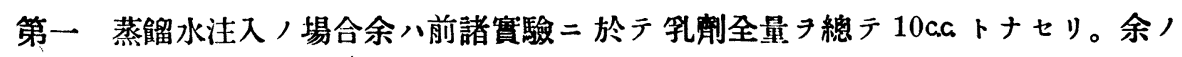
使用七ル乳劑ノ大部ハ主トシテ水分ョリ成ルキ以テ前述七ル變化ハ注入七ル水分二因

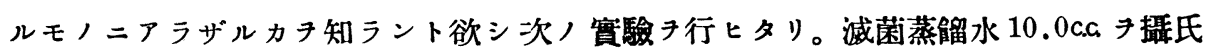
37 度二加溫シ直二健康家鬼腹腔内二注入シ其ノ前後二於ヶル血液瓦斯測定セり。蒸

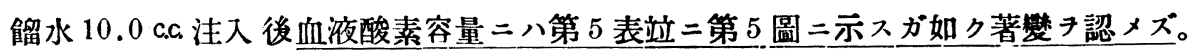
一時輕度ノ減少ヌ來タセドモ漱次常態二復歸セリ。而シテ其ノ變化ノ狀態八健康家兔

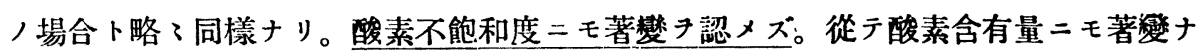
シ。炭酸瓦斯含有量モ健康家鬼ハソレ二略了相一致セリ。是二由テ䚋レバ腹腷內二注 入七ラレタル體溫蒸緭水八吸收七ラレテ血液ノ水分幾分增加セシムべキ理ナルモ. 余，使用七ルガ如キ量 $(10.0 \mathrm{ccc}$ ) ニテハ血液ノ水分二影掣き與へザルモ，、如ク血液瓦

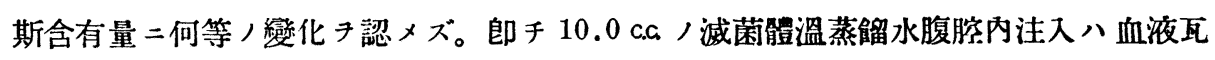

\begin{tabular}{|c|c|c|c|c|c|c|c|c|c|c|c|}
\hline 月 日 & 實驗日 & 䊩色色性 & 體重(硅) & $\begin{array}{l}\text { 時 } \\
\text { 時 }\end{array}$ & $\begin{array}{l}\text { 䦪 } \\
\text { 分 }\end{array}$ & $\begin{array}{l}\text { 蒸䒇水 } \\
\text { 注入量 } \\
\text { (c.c) }\end{array}$ & $\mid$\begin{tabular}{|l|}
$\mid$ 酸素甭丕和度 \\
\end{tabular} & 酸素 & \begin{tabular}{|l|} 
酸素含 \\
量
\end{tabular} & 㟶酸丽 & 酸坌百 \\
\hline \multirow[t]{9}{*}{11,5} & 1 & 24 白 9 & 2,560 & 10 & 30 & & 0.029 & 0.138 & 30.109 & $9|0.435|$ & 79 \\
\hline & & & & 11, & 25 & 10.0 & & & & & \\
\hline & & & & 11, & 35 & & 0.025 & 0.132 & 0.107 & $7 \mid 0.433$ & 81 \\
\hline & & & & 12 & 40 & & 0.025 & 0.133 & \begin{tabular}{l|l}
3 \\
\end{tabular} & 0.434 & 81 \\
\hline & & & & 1, & 40 & & 0.025 & 0.131 & 0.106 & \begin{tabular}{|c|c|} 
& 0.415
\end{tabular} & 81 \\
\hline & & & & 2 , & 40 & & 0.030 & 0.139 & 0.109 & 90.411 & 78 \\
\hline & & & & 3 & 40 & & 0.032 & 0.138 & 0.106 & \begin{tabular}{l|l|}
6 & 0.419
\end{tabular} & 77 \\
\hline & & & & 4, & 40 & & 0.030 & 0.137 & 0.107 & \begin{tabular}{l|l|l|}
7 & 0.403 \\
\end{tabular} & 78 \\
\hline & & & & 5 , & 40 & & 0.026 & 0.135 & \begin{tabular}{|l|l}
5 & 0.109
\end{tabular} & \begin{tabular}{l|l|}
9 & 0.369
\end{tabular} & 81 \\
\hline 11,8 & 4 & & 2,450 & 4 , & 00 & & 0.028 & 0.128 & 0.100 & 0.476 & 78 \\
\hline 11,12 & 8 & & 2,470 & 4 , & 15 & & 0.028 & 0.119 & 0.091 & \begin{tabular}{ll|}
1 & 0.434 \\
\end{tabular} & 77 \\
\hline 11,17 & 13 & & 2,590 & 12, & 50 & & 0.030 & 0.119 & 0.089 & \begin{tabular}{l|l|}
9 & 0.432 \\
\end{tabular} & 75 \\
\hline 11,21 & 17 & & 2,550 & 3 , & 00 & & 0.023 & 0.121 & 0.098 & \begin{tabular}{l|l|}
8 & 0.417 \\
\end{tabular} & 81 \\
\hline 11,25 & 21 & & 2,450 & 11, & 00 & & 0.024 & 0.129 & 0.105 & 50.455 & 81 \\
\hline 11,28 & 24 & & 2,500 & 10 & 00 & & 0.023 & 0.132 & \begin{tabular}{|l|l|}
2 & 0.109
\end{tabular} & 90.412 & 83 \\
\hline 12,5 & 31 & & 2,520 & 3 , & 00 & & 0.027 & 0.123 & \begin{tabular}{l|l|l}
3 & 5.096
\end{tabular} & \begin{tabular}{l|l|}
6 & 0.419
\end{tabular} & 78 \\
\hline 12,10 & 36 & & 2,530 & 1 , & 40 & & 0.023 & $|0.122|$ & 0.099 & \begin{tabular}{l|l}
9 & 0.458 \\
\end{tabular} & 81 \\
\hline
\end{tabular}




\begin{tabular}{|c|c|c|c|c|c|c|c|c|c|c|}
\hline 12,14 & 40 & & 2,560 & 1,45 & & 0.027 & 0.114 & 0.087 & 0.452 & 76 \\
\hline $12, \quad 18$ & 44 & & 2,490 & 1,55 & & 0.025 & 0.113 & 0.088 & 0.422 & 78 \\
\hline 12,20 & 46 & & 2,430 & 1,00 & & 0.023 & 0.110 & 0.087 & 0.438 & 79 \\
\hline 12,25 & 51 & & 2,530 & 12,20 & & 0.026 & 0.127 & 0.101 & 0.446 & 79 \\
\hline 12,30 & 56 & & 2,550 & 10,10 & & 0.024 & 0.133 & 0.109 & 0.428 & 82 \\
\hline 1,5 & 61 & & 2,500 & 2,50 & & 0.021 & 0.141 & 0.120 & 0.477 & 85 \\
\hline 12,24 & 1 & 26 白 $\hat{\delta} \mid$ & 2,500 & $\begin{array}{ll}10, & 20 \\
12, & 05\end{array}$ & 10.0 & 0.020 & 0.121 & 0.101 & 0.432 & 83 \\
\hline & & & & 12,20 & & 0.022 & 0.117 & 0.095 & 0.412 & 81 \\
\hline & & & & 1,20 & & 0.022 & 0.115 & 0.093 & 0.429 & 81 \\
\hline & & & & 2,10 & & 0.020 & 0.114 & 0.094 & 0.412 & 82 \\
\hline & & & & ?, 1.0 & & 0.023 & 0.107 & 0.084 & 0.385 & 79 \\
\hline & & & & 4,10 & & 0.022 & 0.107 & 0.085 & 0.366 & 79 \\
\hline & & & & 5,10 & & 0.022 & 0.113 & 0.091 & 0.358 & 81 \\
\hline 12,25 & 2 & & 2,450 & 11,45 & & 0.022 & 0.110 & 0.088 & 0.498 & 80 \\
\hline 12,27 & 4 & & 2,390 & 11,15 & & 0.021 & 0.110 & 0.089 & 0.422 & 81 \\
\hline
\end{tabular}

第五圖

蒸餾 水 10 c.a. 注入

酸素容量 …… 炭酸瓦斯含有量

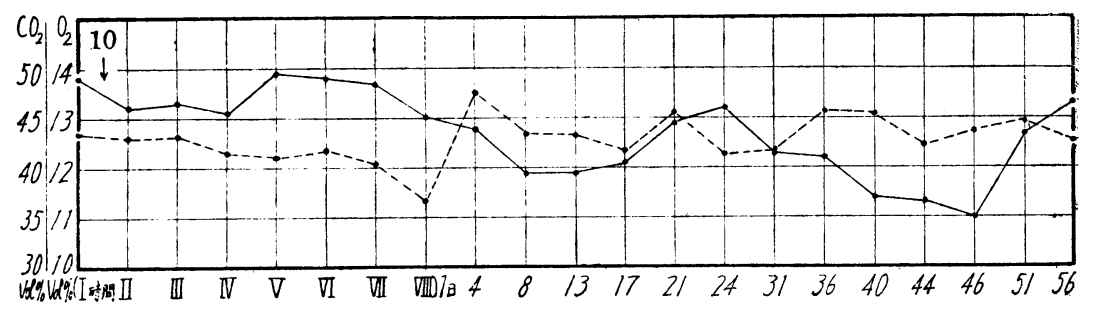

斯二何等ノ影響キ與へズ。

第二 同種性腹膜上皮緗胞成分注入八場合 余心對照試驗, 材料トシテ種々ノ上 皮細胞子使用七リ。特二腹膜及ビ肋膜ハ一層ノ細胞ヨリ成ルチ以テ實驗二供七ント七 ルモ肋膜上皮細胞八剥雄甚ダ困難ニシテ乳劑ノ製造不可能ナリショ以テ腹膜上.皮細胞 ノそチ使用シタリ。同種性腹膜上波細胞乳劑八前述七几方法ト同樣ノ方法ニヨリテ製

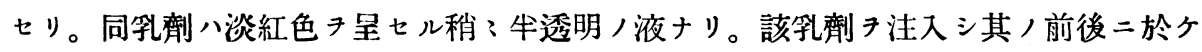
ル血液瓦斯キ測定シ且長期二瓦りテ觀察セリ。第 6 表及ビ第 6 圖二示セルガ如ク pro Kilo 0.01 乃至 pro Kilo 0.02 二於テハ注入後酸素容量/增加テ示スモノナク漸次 減少シ第 2 日目二幾分減少シ No. 29 二於テ八注入後 3 時間頃ヨリ恢復シ著明 減少

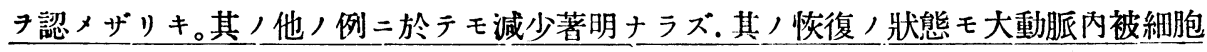




\begin{tabular}{|c|c|c|c|c|c|c|c|c|c|c|c|c|}
\hline \multicolumn{5}{|r|}{ 第 } & \multicolumn{3}{|c|}{ 六 } & \multicolumn{5}{|l|}{ 表 } \\
\hline 月 & 日 & 實驗日 & 番毛色性 & 體重(硅) & & & $\begin{array}{l}\text { 腹膜上皮 } \\
\text { 細胞。孚 } \\
\text { 注入量 }\end{array}$ & $\begin{array}{l}\text { 酸素不 } \\
\text { 哴和度 }\end{array}$ & 酸素 & \begin{tabular}{|l|} 
酸素含 \\
\end{tabular} & $\begin{array}{l}\text { 宸酸瓨 } \\
\text { 斯有含 } \\
\text { 量 }\end{array}$ & 酸素百 \\
\hline \multirow{7}{*}{\multicolumn{2}{|c|}{12,2}} & 1 & 28 白 & 2,200 & 11 , & & & 0.018 & 0.103 & \begin{tabular}{l|l|}
3 & 0.085 \\
\end{tabular} & 0.444 & 82 \\
\hline & & & & & 11, & 55 & 0.01 & & & & & \\
\hline & & & & & 12 & & & 0.020 & 0.101 & 10.081 & 0.412 & so \\
\hline & & & & & 1 , & 10 & & 0.028 & 0.094 & $\begin{array}{lll}4 & 0.066 \\
\end{array}$ & 0.423 & 70 \\
\hline & & & & & 2 , & 10 & & 0.024 & 0.086 & \begin{tabular}{|l|l|}
6 & 0.062 \\
\end{tabular} & 0.403 & 72 \\
\hline & & & & & 3 , & 10 & & 0.030 & 0.086 & \begin{tabular}{|l|l|}
6 & 0.056 \\
\end{tabular} & 0.418 & 65 \\
\hline & & & & & 4, & 30 & & 0.020 & 0.084 & \begin{tabular}{l|l|}
4 & 0.064
\end{tabular} & 0.372 & 76 \\
\hline 12 , & 30 & 2 & & 1,970 & 11 , & 50 & & 0.017 & 0.077 & $\begin{array}{lll}7 & 0.060\end{array}$ & 0.433 & 78 \\
\hline \multirow{2}{*}{1} & 4 & 7 & & 1,720 & 1 , & 00 & & 0.021 & 0.079 & $\begin{array}{lll}9 & 0.058\end{array}$ & 0.418 & 73 \\
\hline & 18 & 11 & & 1,690 & 12 & 20 & & 0.028 & $\mid 0.089$ & $9 \mid 0.061$ & 0.413 & 69 \\
\hline \multirow{7}{*}{\multicolumn{2}{|c|}{1,}} & 1 & 30 白 & 2,180 & 9 , & 50 & & 0.025 & 0.121 & \begin{tabular}{l|l|}
1 & 0.096 \\
\end{tabular} & 0.390 & 79 \\
\hline & & & & & 11, & & 0.01 & & & & & \\
\hline & & & & & 11 , & & & 0.024 & 0.118 & \begin{tabular}{|l|l|}
8 & 0.094 \\
\end{tabular} & 0.414 & 80 \\
\hline & & & & & 12 & 00 & & 0.023 & 0.104 & $\begin{array}{l}4.081 \\
\end{array}$ & 0.335 & 78 \\
\hline & & & & & 1, & 15 & & 0.023 & 0.105 & 50.082 & 0.337 & 78 \\
\hline & & & & & 2 , & 10 & & 0.025 & 0.108 & \begin{tabular}{|l|l|}
8 & 0.083 \\
\end{tabular} & 0.339 & 77 \\
\hline & & & & & 3 & 40 & & 0.023 & 0.099 & \begin{tabular}{l|l|}
9 & 0.076
\end{tabular} & 0.327 & 77 \\
\hline 1, & & 2 & & 2,150 & 9 , & 40 & & 0.021 & 0.104 & \begin{tabular}{l|l|}
4 & 0.083 \\
\end{tabular} & 0.413 & 80 \\
\hline 1 , & 20 & 5 & & 2,120 & 11, & 40 & & 0.018 & 0.108 & 80.090 & 0.460 & 83 \\
\hline 1, & 22 & 7 & & 2,080 & 2 , & 40 & & 0.021 & 0.104 & \begin{tabular}{l|l|}
4 & 0.083
\end{tabular} & 0.433 & 80 \\
\hline 1 , & 25 & 10 & & 2,090 & 1, & 10 & & 0.023 & 0.109 & \begin{tabular}{ll|}
9 & 0.086 \\
\end{tabular} & 0.433 & 79 \\
\hline 1, & 28 & 13 & & 2,050 & 1, & 10 & & 0.023 & 0.110 & $\begin{array}{lll}0 & 0.087\end{array}$ & 0.396 & 79 \\
\hline 1, & 31 & 16 & & 2,090 & 2 , & 30 & & 0.022 & 0.113 & \begin{tabular}{|l|l|} 
& 0.091
\end{tabular} & 0.412 & 80 \\
\hline 2 , & 3 & 19 & & 2,100 & 3, & 40 & & 0.022 & 0.114 & $4 \quad 0.092$ & 0.458 & 81 \\
\hline 2 , & 6 & 22 & & 2,160 & 12, & 30 & & 0.019 & 0.113 & $\begin{array}{lll}3 & 0.094\end{array}$ & 0.460 & 83 \\
\hline & 9 & 25 & & 2,000 & 1, & 30 & & 0.023 & 0.111 & 10.088 & 0.437 & 79 \\
\hline 2, & 12 & 28 & & 1,980 & 11, & 00 & & 0.020 & 0.115 & 50.095 & 0.463 & 83 \\
\hline 2 & 15 & 31 & & 2,090 & 10 & 30 & & 0.017 & 0.098 & $\begin{array}{lll}8 & 0.081\end{array}$ & 0.426 & 83 \\
\hline 2, & 18 & 34 & & 2,220 & 11, & 30 & & 0.018 & 0.097 & 7) 0.079 & 0.410 & 82 \\
\hline 2, & 21 & 37 & & 2,280 & 10 & 20 & & 0.021 & 0.114 & $\begin{array}{ll}4 \quad 0.093 \\
\end{array}$ & 0.363 & 82 \\
\hline 2 , & 24 & 40 & & 2,200 & 10 & 30 & & 0.018 & 0.103 & $\begin{array}{ll}3 & 0.085\end{array}$ & 0.385 & 83 \\
\hline 2, & 27 & 43 & & 2,200 & 10 & 30 & & 0.018 & 0.127 & $\begin{array}{ll}7 & 0.109\end{array}$ & 0.412 & 85 \\
\hline 3 & 2 & 46 & & 2,180 & 10 & 30 & & 0.019 & 0.121 & \begin{tabular}{l|l}
1 & 0.102
\end{tabular} & 0.413 & 84 \\
\hline 3 & 5 & 49 & & 2,200 & 10 & 20 & & 0.018 & 0.126 & \begin{tabular}{l|l}
6 & 0.108
\end{tabular} & 0.402 & 86 \\
\hline & 8 & 52 & & 2,140 & 10 & 20 & & 0.020 & 0.120 & $\begin{array}{lll}0 & 0.100\end{array}$ & 0.390 & 83 \\
\hline 3 & 11 & 55 & & 2,110 & 10 & 20 & & 0.020 & 0.123 & \begin{tabular}{|l|l|} 
& 0.103
\end{tabular} & 0.422 & 84 \\
\hline 3 & 14 & 58 & & 2,090 & 10 & 30 & & 0.020 & 0.126 & $6 \quad 0.106$ & 0.395 & 84 \\
\hline 3 & 17 & 61 & & 2,170 & 9 , & 30 & & 0.023 & 0.126 & \begin{tabular}{|l|l|}
6 & 0.103
\end{tabular} & 0.456 & 82 \\
\hline 3 & 21 & 61 & & 2,160 & 10 & 30 & & 0.019 & 0.127 & $\begin{array}{ll}7 & 0.108\end{array}$ & 0.433 & 85 \\
\hline
\end{tabular}




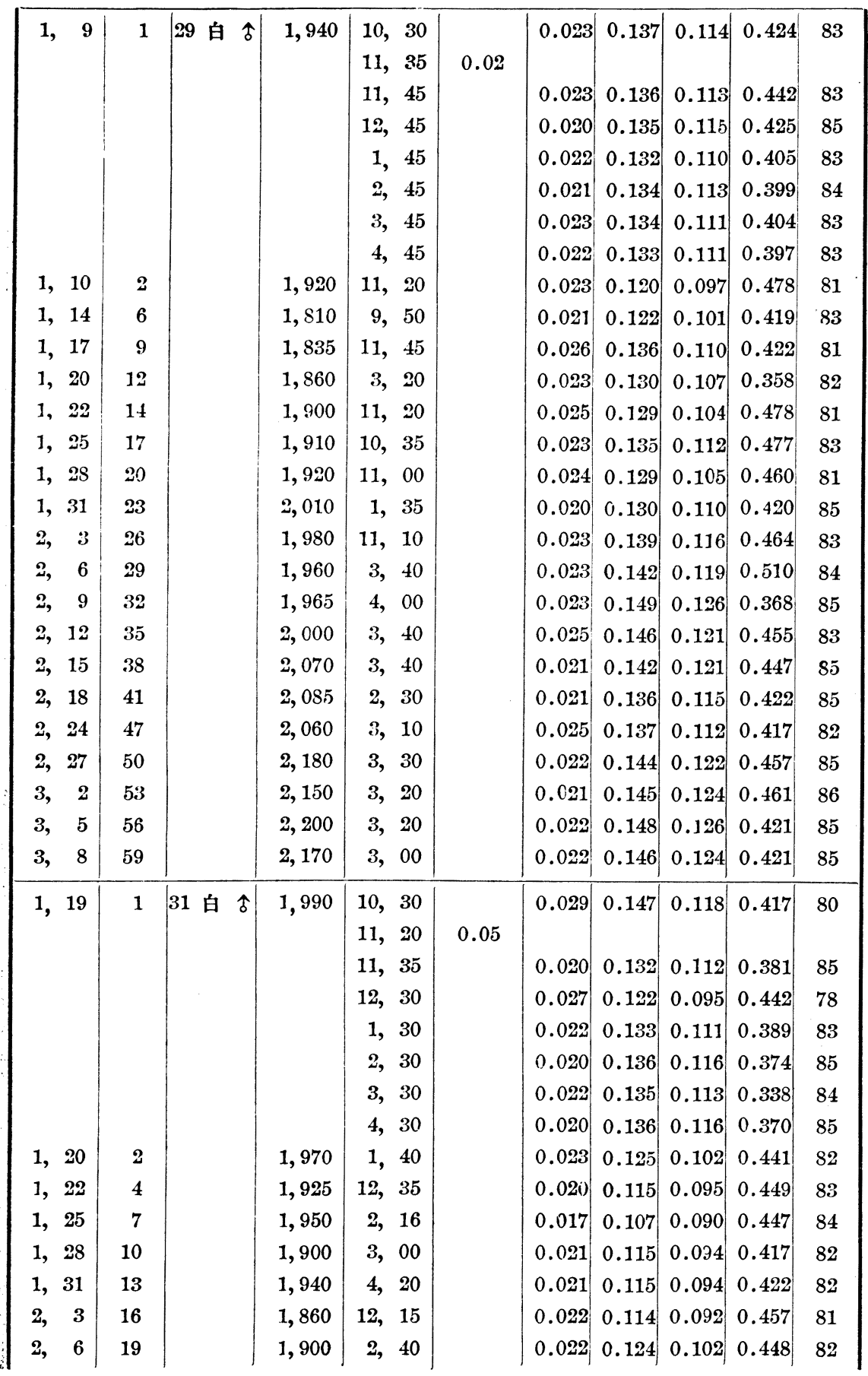




\begin{tabular}{|c|c|c|c|c|c|c|c|c|c|c|}
\hline $2, \quad 9$ & 22 & & 1,835 & 2,40 & & 0.020 & 0.128 & 0.108 & 0.418 & 84 \\
\hline 2,12 & 25 & & 1,900 & 1,45 & & 0.023 & 0.135 & 0.112 & 0.443 & 83 \\
\hline 2,15 & 28 & & $\cdot 1,960$ & 1,00 & & 0.021 & 0.130 & 0.109 & 0.128 & 84 \\
\hline 2,18 & 31 & & $\mathbf{2}, 000$ & $1, \mathrm{C} 0$ & & 0.024 & 0.133 & 0.109 & 0.439 & 82 \\
\hline 2,24 & 37 & & 1,910 & 2,00 & & 0.023 & 0.125 & 0.102 & 0.390 & 82 \\
\hline 2,27 & 40 & & 1,910 & 2,15 & & 0.021 & 0.141 & 0.120 & 0.419 & 85 \\
\hline $3, \quad 2$ & 43 & & 1,940 & 1,40 & & 0.025 & 0.143 & 0.118 & 0.434 & 83 \\
\hline $3, \quad 5$ & 47 & & 1,900 & 1,40 & & 0.019 & 0.148 & 0.129 & 0.451 & 87 \\
\hline 3,14 & 56 & & 1,840 & 1,30 & & 0.023 & 0.142 & 0.119 & 0.367 & 84 \\
\hline 3,18 & 60 & & 1,850 & 1,00 & & 0.021 & 0.151 & 0.130 & 0.398 & 86 \\
\hline 3,21 & 63 & & 1,925 & 12,30 & & 0.022 & 0.152 & 0.130 & 0.411 & 85 \\
\hline 1,24 & 1 & 32 白 & 2,300 & 10,30 & & 0.020 & 0.135 & 0.115 & 0.345 & 85 \\
\hline & & & & $\begin{array}{ll}11, & 30 \\
11, & 45\end{array}$ & 0.05 & 0.017 & 0.128 & 0.111 & 0.340 & 87 \\
\hline & & & & 12,45 & & 0.016 & 0.126 & 0.110 & 0.349 & 87 \\
\hline & & & & 1,45 & & 0.019 & 0.121 & 0.102 & $0.331_{j}$ & 84 \\
\hline & & & & 2,45 & & 0.019 & 0.127 & 0.108 & 0.338 & 85 \\
\hline & & & & 3,40 & & 0.017 & 0.126 & 0.109 & 0.315 & 87 \\
\hline & & & & 4,40 & & 0.019 & 0.107 & 0.088 & 0.307 & 82 \\
\hline 1,25 & 2 & & 2,000 & 9,40 & & 0.016 & 0.098 & 0.082 & 0.292 & 84 \\
\hline 1,30 & 1 & 33 白 $\hat{8}$ & 1,800 & 10,20 & & 0.019 & 0.136 & 0.117 & 0.417 & 86 \\
\hline & & & & 11,25 & 0.1 & & & & & \\
\hline & & & & 11,40 & & 0.025 & 0.112 & 0.087 & 0.460 & 78 \\
\hline & & & & 12,30 & & 0.024 & 0.130 & 0.106 & 0.420 & 82 \\
\hline & & & & 1,35 & & 0.020 & 0.135 & 0.115 & 0.405 & 85 \\
\hline & & & & 2,35 & & 0.023 & 0.130 & 0.107 & 0.388 & 82 \\
\hline & & & & 3,35 & & 0.022 & 0.129 & 0.107 & 0.418 & 83 \\
\hline & & & & 4,35 & & 0.033 & 0.128 & 0.105 & 0.383 & 82 \\
\hline 1,31 & 2 & & 1,720 & $12,4 j$ & & 0.022 & 0.118 & 0.096 & 0.438 & 81 \\
\hline $2, \quad 3$ & 5 & & 1,840 & 1,45 & & 0.083 & 0.123 & 0.100 & 0.424 & 81 \\
\hline $2, \quad 6$ & 8 & & 1,835 & 1,35 & & 0.020 & 0.134 & 0.114 & 0.441 & 85 \\
\hline $2, \quad 9$ & 11 & & 1,765 & 10,55 & & 0.025 & 0.129 & 0.104 & $0.448^{\prime}$ & 81 \\
\hline 2,12 & 14 & & 1,810 & 11,30 & & 0.021 & 0.134 & 0.113 & $0 \cdot 429$ & 84 \\
\hline 2,14 & 16 & & 1,850 & 12,10 & & 0.020 & 0.125 & 0.105 & 0.434 & 84 \\
\hline 2,17 & 19 & & 1,820 & 11,40 & & 0.024 & 0.135 & 0.111 & 0.491 & 82 \\
\hline 2,20 & 22 & & 1,825 & 11,00 & & 0.022 & 0.128 & 0.106 & 0.487 & 84 \\
\hline 2,24 & 26 & & 1,900 & 12,30 & & 0.025 & 0.112 & 0.087 & 0.403 & 78 \\
\hline 2,27 & 29 & & 1,920 & 12,40 & & 0.019 & 0.111 & 0.092 & 0.442 & 83 \\
\hline $3, \quad 2$ & 31 & & 1,915 & 11,40 & & 0.023 & 0.123 & 0.100 & 0.495 & 81 \\
\hline $3, \quad 5$ & 34 & & 1,930 & 12,00 & & 0.020 & 0.126 & 0.106 & 0.468 & 84 \\
\hline $3, \quad 8$ & 37 & & 1,900 & 11,30 & & 0.024 & 0.135 & 0.111 & 0.458 & 82 \\
\hline 3,11 & 40 & & 1,935 & 1,30 & & 0.023 & 0.137 & 0.114 & 0.406 & 83 \\
\hline
\end{tabular}


佐藤 $=$ 非經口的二注入セル大動脈壁細胞成分ノ血熙及血液瓦斯 $=$ 及ボス影䈏二就テ 828

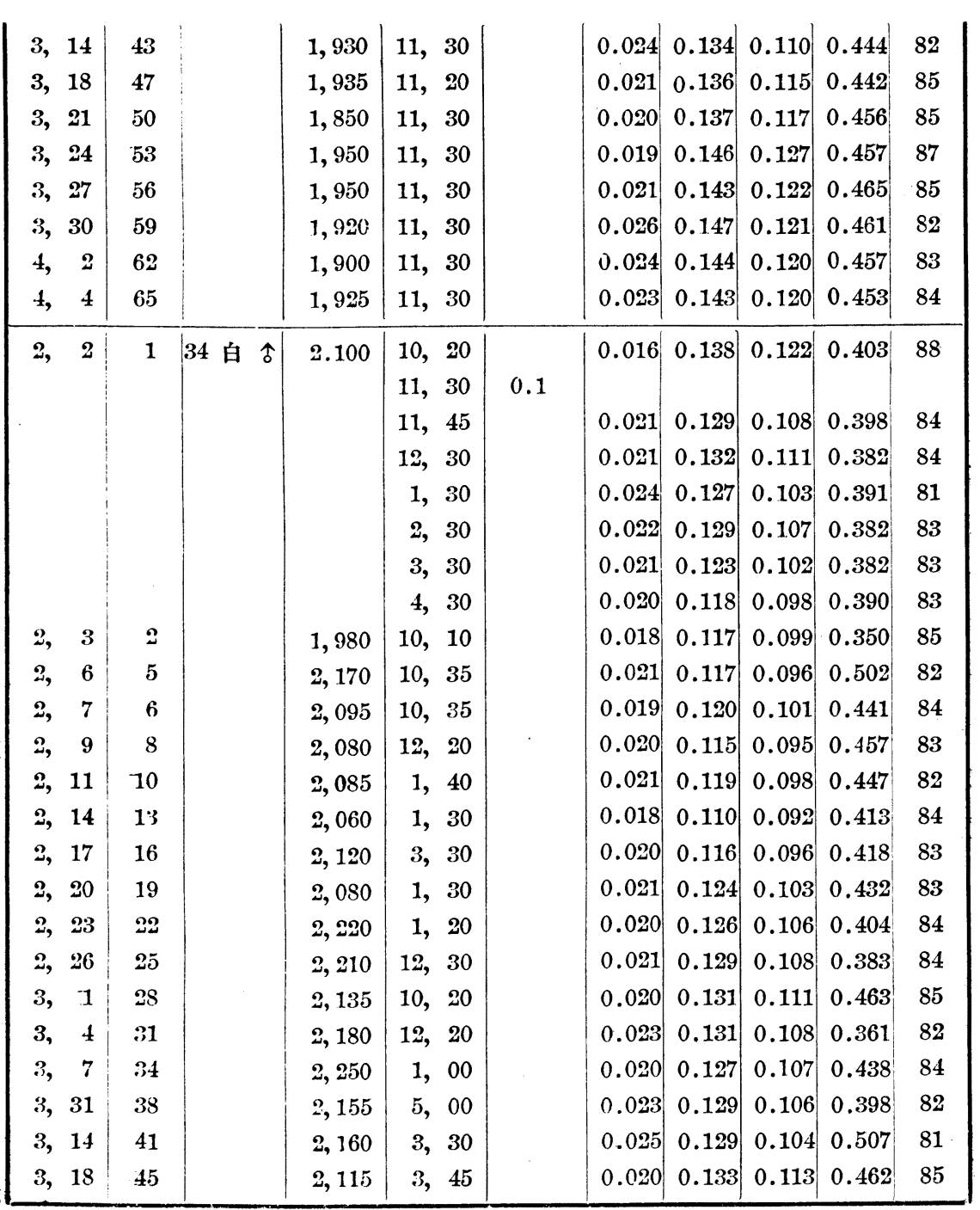

第六㖥 股膜_上皮細胞乳劑注入 (pro kilo 0.01) (30號) 酸素容量 - - - - - 炭酸瓦斯含有量

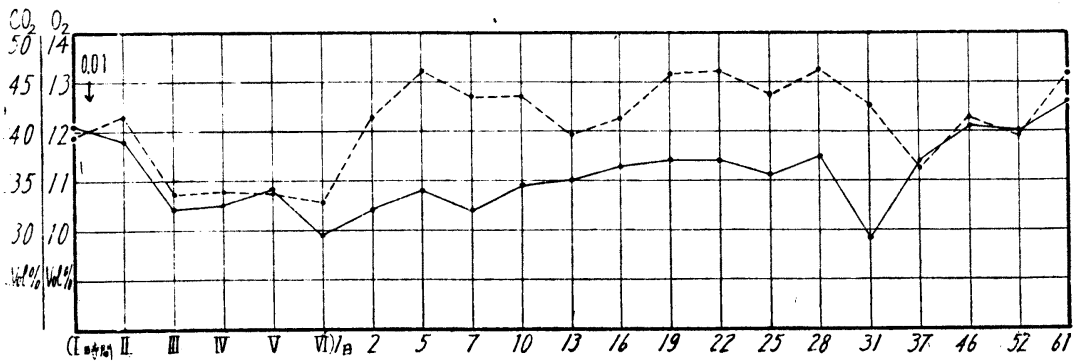


824 佐藤=非經口的二注入セル大動脈壁細胞成分，血壓及血液瓦斯二及ポス影篦二就テ

第七圆 腹膜上皮細胞乳㷰注入 (pro kilo 0.1) (34諕)

酸素容量

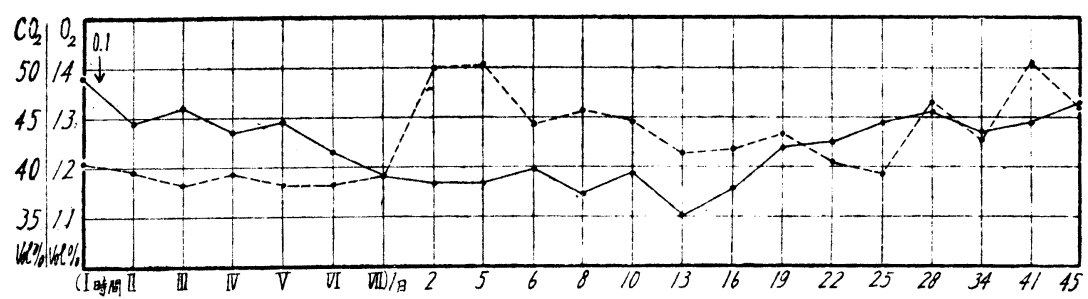

乳刺ノ場合二比較シテ幾分速二シテ pro Kilo 0.05 乃至 pro Kilo 0.1 ニアリテハ (第 7 圖)第 1 日八減少八著明ナラズシテ。小量洼入，場合ト異ナルコトナキモ長期， 經過ニアリテハ其ノ減少，度モ幾分强ク恢復ノ狀態モ小量/場合二比較シテ幾分逮延 七ルモノ、如シ。酸素不飽和度八何レノ場合モ著變キ認メズ。從テ酸素含有量八酸素

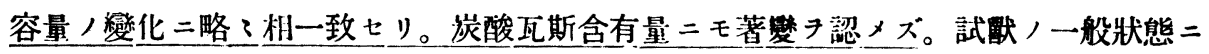
於テモ著變ナク健康家鬼ノ場合卜略 了同樣ナリ。要スル二腹腔上皮細胞成分ノ注入二 ヨリテ血液瓦斯二八著明ノ變化フ認メズ。

第三 同種性胃粘膜上皮細胞成分注入，場合 余八更二眾腸粘膜等，多屏上皮細胞 成分ガ血液瓦斯二如何ナル影掣き及ボスベキカタ知ラント欲シ上述七ル力法二從七是

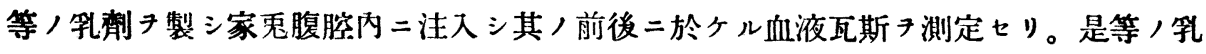
劑ハ粘膜ヨリ剝離七ルガ故二上皮緗胞以外，粘液及ビ其／他不明ノ成分／混入スルォ 免レズ。勿論無菌的操作ニヨリテ製セルモ初メヨリ存在セル細菌等モ多少混入七ルモ ノト考へザルベカラズ。然レドモ實驗二際シ特二一般狀息二就テ觀察七ル二何等著明:

第 七 表

\begin{tabular}{|c|c|c|c|c|c|c|c|c|c|c|c|c|}
\hline \multirow{2}{*}{\multicolumn{2}{|c|}{$\begin{array}{l}\text { 月 } \quad \text { 日 } \\
3,29\end{array}$}} & \multirow{2}{*}{$\frac{\mid \text { 實驗 }}{1}$} & \multicolumn{2}{|c|}{ 榣毛色 性能重(硅) } & \multicolumn{2}{|c|}{$\begin{array}{l}\text { 時 閔 } \\
\text { 時 } \\
\end{array}$} & \multicolumn{2}{|c|}{ 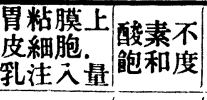 } & \multicolumn{4}{|c|}{ 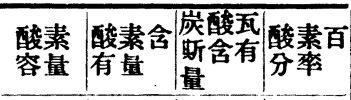 } \\
\hline & & & 54 白 5 & 1,900 & $\begin{array}{l}10, \\
11,\end{array}$ & & 0.005 & 0.020 & 0.161 & 0.141 & 0.424 & 87 \\
\hline & & & & & 11, & 10 & & 0.023 & 0.152 & 0.129 & 0.438 & 85 \\
\hline & & & & & 12 , & 30 & & 0.024 & 0.160 & 0.136 & 0.412 & 85 \\
\hline & & & & & 1 , & 30 & & 0.027 & 0.163 & 0.136 & 0.411 & 84 \\
\hline & & & & & 2 , & 30 & & 0.027 & 0.160 & 0.133 & 0.410 & 83 \\
\hline & & & & & 3 , & 30 & & 0.026 & 0.151 & 0.125 & 0.397 & 83 \\
\hline & & & & & 4 , & 0 & & 0.026 & 0.149 & 0.123 & 0.390 & 83 \\
\hline 3 & & 2 & & 1,860 & 10, & 30 & & 0.022 & 0.143 & 0.121 & 0.476 & 85 \\
\hline 4 & 2 & 5 & & 1,875 & 10 & 30 & & 0.021 & 0.146 & 0.125 & 0.420 & 86 \\
\hline 4, & 4 & 7 & & 1,710 & 11, & 00 & & 0.028 & 0.150 & 0.122 & 0.432 & 81 \\
\hline
\end{tabular}




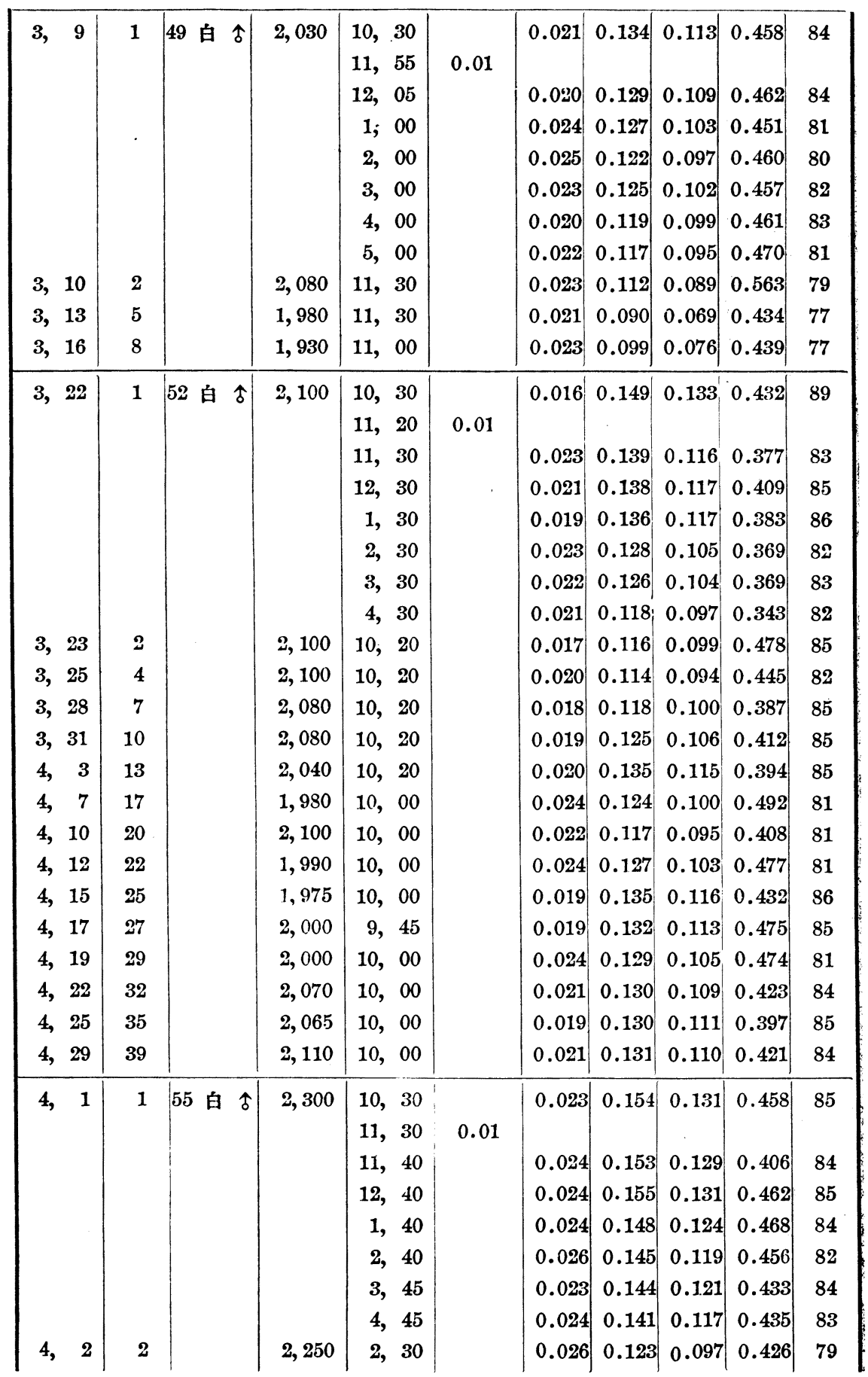




\begin{tabular}{|c|c|c|c|c|c|c|c|c|c|c|}
\hline $4, \quad 4$ & 4 & & 2,160 & 2,30 & & 0.022 & 0.115 & 0.093 & 0.430 & 81 \\
\hline 4,7 & 7 & & 2,260 & 2,30 & & 0.024 & 0.114 & 0.090 & 0.452 & 79 \\
\hline 4,10 & 10 & & 2,260 & 2,30 & & 0.023 & 0.126 & 0.103 & 0.461 & 82 \\
\hline 4,13 & 13 & & 2,340 & 2,30 & & 0.023 & 0.131 & 0.108 & 0.428 & 82 \\
\hline 4,15 & 15 & & 2,235 & 2,30 & & 0.026 & 0.129 & 0.103 & 0.451 & 80 \\
\hline 4,17 & 17 & & 2,250 & 2,30 & & 0.028 & 0.132 & 0.109 & 0.455 & 83 \\
\hline 4,19 & 19 & & 2,210 & 3,00 & & 0.024 & 0.125 & 0.101 & 0.493 & 81 \\
\hline 4,22 & 22 & & 2,250 & 3,00 & & 0.022 & 0.124 & 0.102 & 0.433 & 82 \\
\hline 4,25 & 25 & & 2,230 & 3,00 & & 0.024 & 0.127 & 0.103 & 0.452 & 81 \\
\hline $5, \quad 3$ & 29 & & 2,250 & 3,00 & & 0.026 & 0.124 & 0.098 & 0.426 & 79 \\
\hline $5, \quad 6$ & 35 & & 2,210 & 4,00 & & 0.024 & 0.127 & 0.103 & 0.438 & 81 \\
\hline $5, \quad 9$ & 38 & & 2,210 & 4,00 & & 0.026 & 0.127 & 0.101 & 0.452 & 80 \\
\hline \multirow[t]{7}{*}{4,11} & 1 & 57 白 & 1,910 & 10,00 & \multirow{16}{*}{0.01} & 0.021 & 0.129 & 0.108 & 0.432 & 84 \\
\hline & & & & 10,50 & & & & & & \\
\hline & & & & 11,00 & & 0.026 & 0.127 & 0.101 & 0.480 & 80 \\
\hline & & & & 12,00 & & 0.025 & 0.120 & 0.095 & 0.490 & 79 \\
\hline & & & & 1,00 & & 0.026 & 0.117 & 0.091 & 0.445 & 78 \\
\hline & & & & 2,00 & & 0.022 & 0.111 & 0.089 & 0.440 & 80 \\
\hline & & & & 3,00 & & 0.026 & 0.103 & 0.077 & 0.426 & 75 \\
\hline 4,12 & 2 & & 1,890 & 12,20 & & 0.023 & 0.088 & 0.065 & 0.462 & 74 \\
\hline 4,15 & 5 & & 1,725 & 1,00 & & 0.023 & 0.092 & 0.069 & 0.437 & 75 \\
\hline 4,17 & 7 & & 1,840 & 1,00 & & 0.020 & 0.114 & 0.094 & 0.426 & 82 \\
\hline 4,19 & 9 & & 1,760 & 1,00 & & 0.024 & 0.129 & 0.105 & 0.433 & 81 \\
\hline 4,82 & 12 & & 1,740 & 1,00 & & 0.024 & 0.137 & 0.113 & 0.400 & 82 \\
\hline 4,24 & 14 & & 1,680 & 1,00 & & 0.021 & 0.134 & 0.113 & 0.375 & 84 \\
\hline 4,27 & 17 & & 1,740 & 1,00 & & 0.025 & 0.131 & 0.106 & 0.395 & 81 \\
\hline 4,30 & 20 & & 1,720 & 1,00 & & 0.026 & 0.136 & 0.110 & 0.337 & 81 \\
\hline $5, \quad 2$ & 22 & & 1,680 & 1,00 & & 0.024 & 0.137 & 0.113 & 0.358 & 82 \\
\hline \multirow[t]{8}{*}{3,13} & 1 & 50 白 $\hat{\delta}$ & 2,160 & 10,30 & \multirow{9}{*}{0.05} & 0.022 & 0.154 & 0.132 & 0.428 & 86 \\
\hline & & & & 11,20 & & & & & & \\
\hline & & & & 11,30 & & 0.026 & 0.152 & 0.126 & 0.412 & 83 \\
\hline & & & & 12,30 & & 0.021 & 0.148 & 0.127 & 0.418 & 86 \\
\hline & & & & 1,30 & & 0.022 & 0.149 & 0.127 & 0.418 & 85 \\
\hline & & & & 2,30 & & 0.024 & 0.147 & 0.123 & 0.422 & 84 \\
\hline & & & & 3,30 & & 0.024 & 0.145 & 0.121 & 0.401 & 83 \\
\hline & & & & 4,30 & & 0.025 & 0.146 & 0.121 & 0.403 & 83 \\
\hline 3,16 & 2 & & 1,950 & & & 0.020 & 0.140 & 0.120 & 0.447 & 86 \\
\hline \multirow[t]{4}{*}{3,19} & 1 & 51 白 今 & 2,060 & 9,40 & \multirow{4}{*}{0.1} & 0.019 & 0.144 & 0.125 & 0.420 & 87 \\
\hline & & & & 10,50 & & & & & & \\
\hline & & & & 11,00 & & 0.019 & 0.144 & 0.125 & 0.461 & 87 \\
\hline & & & & 12,00 & & 0.022 & 0.145 & 0.123 & 0.420 & 85 \\
\hline
\end{tabular}




\begin{tabular}{|c|c|c|c|c|c|c|c|c|}
\hline & & & 1,00 & 0.020 & 0.139 & 0.119 & 0.365 & 86 \\
\hline & & & 2,00 & 0.020 & 0.138 & 0.118 & 0.361 & 85 \\
\hline & & & 3,00 & 0.020 & 0.134 & 0.114 & 0.373 & 85 \\
\hline & & & 4,00 & 0.020 & 0.128 & 0.108 & 0.385 & 84 \\
\hline 3,20 & 2 & 1,880 & 3,00 & 0.023 & 0.123 & 0.100 & 0.421 & 81 \\
\hline 3,23 & 5 & 1,910 & 2,00 & 0.022 & 0.138 & 0.116 & 0.438 & 84 \\
\hline 3,25 & 7 & 1,910 & 2,00 & 0.024 & 0.148 & 0.124 & 0.413 & 84 \\
\hline 3,28 & 8 & 1,970 & 2,00 & 0.022 & 0.156 & 0.134 & 0.368 & 86 \\
\hline 3,31 & 13 & 1,810 & 2,00 & 0.021 & 0.146 & 0.125 & 0.405 & 86 \\
\hline
\end{tabular}

第 $八$

圖

剡粘膜上細胞乳劑注入 (pro kilo 0.01) (52 號)

- - - 酸素容量 - - - - - 岸酸瓦斯含有量

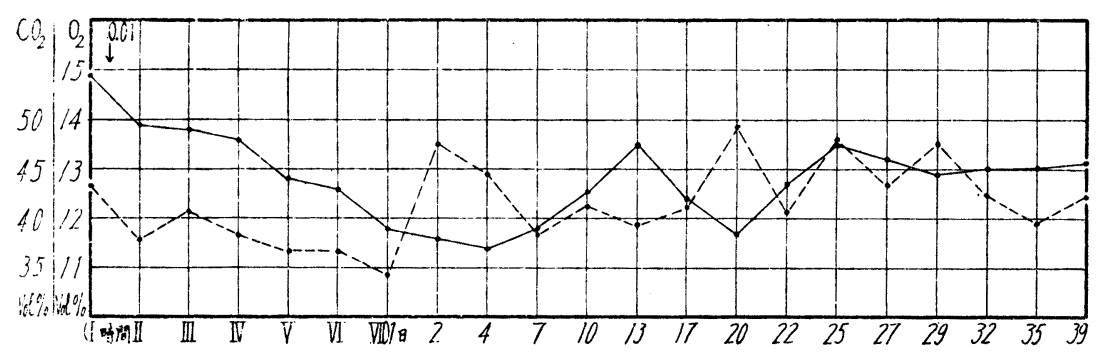

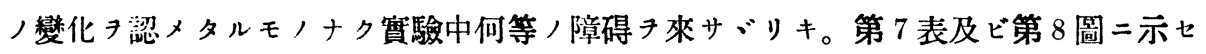
ルガ如ク酸素容量八大量注入，場合二於テ八輕度，減少き來七ルモ著明ナラズ。小量 儿場合二於テハ㱠ド變华ナク。適當量注入八場合ニアリテハ(No. 38, No. 39)酸素 容量ノ減少稍々荖明ナルモノアリ。酸素不飽和度ハ大量及ビ小量何レノ場合二モ著變 隹認メズ。從テ酸素含有量八酸素容量二略々一致セり。炭酸瓦斯含有量モ何レノ場合 ニモ著變ナク適常量注入八場合二八酸素容量，減少時二作七稍了著明ノ增加タ示シ漸 次低下シテ常態以下トナリ，以後幾分動搖キ示シッ、常態二復歸セリ。一般狀態二於

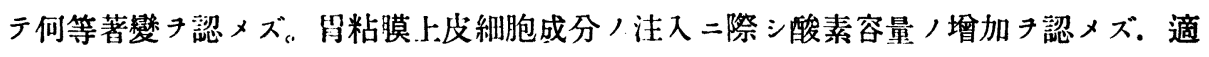
當量注入ニョリ輕度, 減少認ム。

第四同種性腸粘膜上皮細胞成分注入，場合 余八更二同種性腸粘膜上皮細胞乳劑

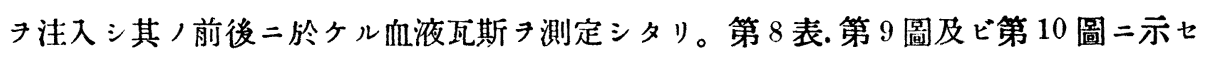
ルガ如ク酸素容量八注入量，如何二拘ラズ著明/變化き來サズ. 一旦減少セルモ直二 常態二復セり。長期，經過二於テハ其，恢復稍了速カナルガ如ク或ルモノ八正常以上 二達セルモノアリ。酸素不飽和度二著變子涊メズ。從テ酸素含有量八酸素容量二立行

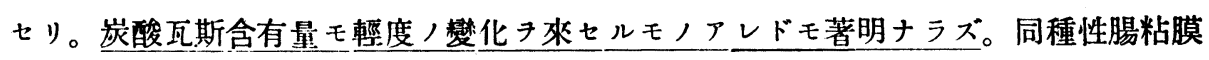




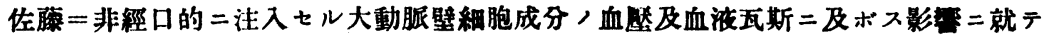

第表

\begin{tabular}{|c|c|c|c|c|c|c|c|c|c|c|c|c|c|}
\hline 月 & 日 & 實驗日 & 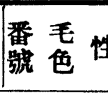 & 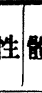 & 量重(硅) & 時 & & 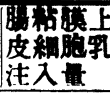 & 缕素不 & $\begin{array}{l}\text { 酸素 } \\
\text { 容 }\end{array}$ & \begin{tabular}{|l|} 
酸素含 \\
量
\end{tabular} & 宸酸螅 & $\begin{array}{l}\text { 酸素百 } \\
\text { 分卒 }\end{array}$ \\
\hline 3 , & 3 & 1 & 42 白 & & 2,050 & $\begin{array}{l}10, \\
12, \\
12, \\
1, \\
2, \\
3, \\
4, \\
5,\end{array}$ & $\begin{array}{l}40 \\
00 \\
10 \\
00 \\
00 \\
00 \\
00 \\
00\end{array}$ & 0.005 & $\begin{array}{l}0.019 \\
0.025 \\
0.024 \\
0.027 \\
0.024 \\
0.023 \\
0.023\end{array}$ & $\begin{array}{l}0.138 \\
0.132 \\
0.139 \\
0.136 \\
0.136 \\
0.134 \\
0.133\end{array}$ & $\mid \begin{array}{l}0.119 \\
0.107 \\
0.115 \\
0.109 \\
0.112 \\
0.111 \\
0.110\end{array}$ & \begin{tabular}{|l|}
0.338 \\
0.393 \\
0.360 \\
0.352 \\
0.349 \\
0.349 \\
0.331
\end{tabular} & $\begin{array}{l}86 \\
\\
78 \\
83 \\
80 \\
82 \\
83 \\
83\end{array}$ \\
\hline $\begin{array}{l}3, \\
3, \\
3, \\
3, \\
3, \\
3,\end{array}$ & $\begin{array}{r}7 \\
10 \\
13 \\
17 \\
20 \\
23\end{array}$ & $\begin{array}{r}2 \\
5 \\
8 \\
12 \\
15 \\
18\end{array}$ & 48 白 & & 2,080 & $\begin{array}{r}10, \\
11, \\
11, \\
12, \\
1, \\
2, \\
3, \\
4, \\
12, \\
10, \\
12, \\
12, \\
12, \\
11,\end{array}$ & $\begin{array}{l}30 \\
25 \\
35 \\
30 \\
30 \\
30 \\
30 \\
30 \\
40 \\
30 \\
10 \\
10 \\
00 \\
30\end{array}$ & 0.005 & $\begin{array}{l}0.022 \\
0.028 \\
0.026 \\
0.024 \\
0.025 \\
0.028 \\
0.030 \\
0.022 \\
0.026 \\
0.022 \\
0.025 \\
0.025 \\
0.023\end{array}$ & $\begin{array}{l}0.131 \\
0.133 \\
0.125 \\
0.127 \\
0.125 \\
0.124 \\
0.118 \\
0.102 \\
0.117 \\
0.119 \\
0.129 \\
0.124 \\
0.128\end{array}$ & \begin{tabular}{|l|}
0.109 \\
0.105 \\
0.099 \\
0.103 \\
0.100 \\
0.096 \\
0.088 \\
0.080 \\
0.091 \\
0.097 \\
0.104 \\
0.099 \\
0.105
\end{tabular} & \begin{tabular}{|l|}
0.416 \\
0.374 \\
0.412 \\
0.383 \\
0.375 \\
0.358 \\
0.349 \\
0.473 \\
0.423 \\
0.390 \\
0.384 \\
0.406 \\
0.410
\end{tabular} & $\begin{array}{l}83 \\
79 \\
79 \\
81 \\
80 \\
77 \\
75 \\
78 \\
78 \\
81 \\
81 \\
80 \\
82\end{array}$ \\
\hline $\begin{array}{l}2, \\
2, \\
2\end{array}$ & $\begin{array}{l}17 \\
20 \\
23\end{array}$ & $\begin{array}{l}2 \\
5 \\
8\end{array}$ & 38 白 & & $\begin{array}{l}2,230 \\
2,210 \\
2,240\end{array}$ & $\begin{array}{r}10, \\
11, \\
11, \\
12, \\
1, \\
3, \\
4, \\
5, \\
10, \\
10, \\
10,\end{array}$ & $\begin{array}{l}30 \\
35 \\
45 \\
45 \\
55 \\
10 \\
10 \\
10 \\
20 \\
00 \\
00\end{array}$ & 0.01 & $\begin{array}{l}0.017 \\
0.022 \\
0.016 \\
0.018 \\
0.023 \\
0.023 \\
0.023 \\
0.023 \\
0.017 \\
0.021\end{array}$ & $\begin{array}{l}0.124 \\
0.112 \\
0.114 \\
0.116 \\
0.112 \\
0.111 \\
0.112 \\
0.104 \\
0.109 \\
0.106\end{array}$ & \begin{tabular}{|l|}
0.107 \\
0.090 \\
0.098 \\
0.098 \\
0.089 \\
0.088 \\
0.089 \\
0.081 \\
0.092 \\
0.085
\end{tabular} & \begin{tabular}{|l|}
0.397 \\
0.430 \\
0.504 \\
0.453 \\
0.457 \\
0.414 \\
0.395 \\
0.465 \\
0.399 \\
0.427
\end{tabular} & $\begin{array}{l}86 \\
80 \\
86 \\
84 \\
79 \\
79 \\
79 \\
78 \\
84 \\
80\end{array}$ \\
\hline 2 & 19 & 1 & 39 白 & & 2,160 & $\begin{array}{r}10, \\
11, \\
11, \\
12, \\
1,\end{array}$ & $\begin{array}{l}00 \\
00 \\
10 \\
15 \\
15\end{array}$ & 0.01 & $\begin{array}{l}0.018 \\
0.022 \\
0.023 \\
0.021\end{array}$ & $\begin{array}{l}0.124 \\
0.104 \\
0.114 \\
0.117\end{array}$ & \begin{tabular}{|l|}
0.106 \\
0.082 \\
0.091 \\
0.096
\end{tabular} & \begin{tabular}{|l|}
0.384 \\
0.503 \\
0.455 \\
0.439
\end{tabular} \mid & $\begin{array}{l}86 \\
79 \\
80 \\
82\end{array}$ \\
\hline
\end{tabular}




\begin{tabular}{|c|c|c|c|c|c|c|c|c|c|c|}
\hline & & & & 2,15 & & 0.023 & 0.114 & 0.091 & 0.437 & 80 \\
\hline & & & & 3,15 & & 0.022 & 0.110 & 0.088 & 0.408 & 80 \\
\hline & & & & 4,15 & & 0.021 & 0.115 & 0.094 & 0.401 & 82 \\
\hline 2,20 & 2 & & 2,130 & 3,30 & & 0.020 & 0.119 & 0.099 & 0.484 & 83 \\
\hline 2,23 & 5 & & 1,970 & 3,30 & & 0.021 & 0.096 & 0.075 & 0.398 & 78 \\
\hline 2,26 & 8 & & 1,970 & 3,00 & & 0.020 & 0.104 & 0.084 & 0.396 & 81 \\
\hline $3, \quad 1$ & 11 & & 1,880 & 3,00 & & 0.022 & 0.110 & 0.088 & 0.457 & 80 \\
\hline $3, \quad 4$ & 14 & & 1,870 & 2,30 & & 0.021 & 0.115 & 0.094 & 0.422 & 82 \\
\hline $3, \quad 7$ & 17 & & 1,940 & 3,30 & & 0.020 & 0.123 & 0.103 & 0.382 & 84 \\
\hline 3,10 & 20 & & 1,900 & 2,40 & & 0.022 & 0.116 & 0.094 & 0.383 & 81. \\
\hline 3,13 & 23 & & 1,880 & 4,00 & & 0.019 & $\begin{array}{lll}0 & 112\end{array}$ & 0.093 & 0.417 & 83 \\
\hline 3,17 & 27 & & 1,890 & 3,30 & & 0.021 & 0.117 & 0.096 & 0.412 & 82 \\
\hline 3,20 & 30 & & 1,885 & 4,00 & & 0.025 & 0.120 & 0.095 & 0.379 & 79 \\
\hline 3,23 & 33 & & 1,960 & 3,30 & & 0.019 & 0.112 & 0.093 & 0.401 & 83 \\
\hline 3,25 & 35 & & 1,930 & 3,30 & & 0.021 & 0.115 & 0.094 & 0.387 & 82 \\
\hline 3,28 & 38 & & 2,000 & 3,30 & & 0.022 & 0.115 & 0.093 & 0.415 & 81 \\
\hline 3,31 & 41 & & 2,010 & 3,30 & & 0.019 & 0.126 & 0.107 & 0.403 & 85 \\
\hline $4, \quad 3$ & 44 & & 2,000 & 3,30 & & 0.024 & 0.126 & 0.102 & 0.417 & 81 \\
\hline 4,8 & 49 & & 2,020 & 3,30 & & 0.023 & 0.133 & 0.110 & 0.399 & 83 \\
\hline 4,15 & 56 & & 2,130 & 3,30 & & 0.021 & 0.139 & 0.118 & 0.408 & 85 \\
\hline 2,22 & 1 & 40 白 $\widehat{f}$ & $?, 000$ & 10,20 & & 0.024 & 0.133 & 0.109 & 0.376 & 82 \\
\hline & & & & 11,20 & 0.05 & & & & & \\
\hline & & & & 11,30 & & 0.028 & 0.127 & 0.099 & 0.492 & 78 \\
\hline & & & & 12,40 & & 0.030 & 0.130 & 0.100 & 0.453 & 77 \\
\hline & & & & 1,40 & & 0.025 & 0.128 & 0.103 & 0.378 & 80 \\
\hline & & & & 2,40 & & 0.028 & 0.132 & 0.104 & 0.363 & 79 \\
\hline & & & & 3,40 & & 0.027 & 0.125 & 0.098 & 0.369 & 79 \\
\hline & & & & 4,44 & & 0.024 & 0.128 & 0.104 & 0.365 & 81 \\
\hline 2,25 & 1 & 41 白 $\widehat{8}$ & 2,160 & 10,00 & & 0.024 & 0.112 & 0.088 & 0.399 & 79 \\
\hline & & & & 11,00 & 0.05 & & & & & \\
\hline & & & & 11,10 & & 0.024 & 0.108 & 0.084 & 0.406 & 78 \\
\hline & & & & 12,15 & & 0.023 & 0.105 & 0.082 & 0.385 & 78 \\
\hline & & & & 1,15 & & 0.025 & 0.103 & 0.078 & 0.399 & 76 \\
\hline & & & & 2,15 & & 0.023 & 0.103 & 0.080 & 0.397 & 78 \\
\hline & & & & 3,15 & & 0.022 & 0.104 & 0.082 & 0.387 & 79 \\
\hline & & & & 4,15 & & 0.021 & 0.101 & 0.080 & 0.389 & 79 \\
\hline 2,26 & 2 & & 2,130 & 10,30 & & 0.017 & 0.093 & 0.076 & 0.457 & 82 \\
\hline $3, \quad 1$ & 5 & & 2,190 & 11,40 & & 0.020 & 0.100 & 0.080 & 0.467 & 80 \\
\hline $3, \quad 4$ & 8 & & 2,200 & 10,30 & & 0.019 & 0.121 & 0.102 & 0.459 & 84 \\
\hline $3, \quad 7$ & 11 & & 2,250 & 10,30 & & 0.020 & 0.125 & 0.105 & 0.460 & 84 \\
\hline 3,11 & 15 & & 2,250 & 11,50 & & 0.022 & 0.117 & 0.095 & 0.478 & 81 \\
\hline 3,13 & 18 & & 2,150 & 10,45 & & 0.021 & 0.127 & 0.106 & 0.492 & 83 \\
\hline
\end{tabular}




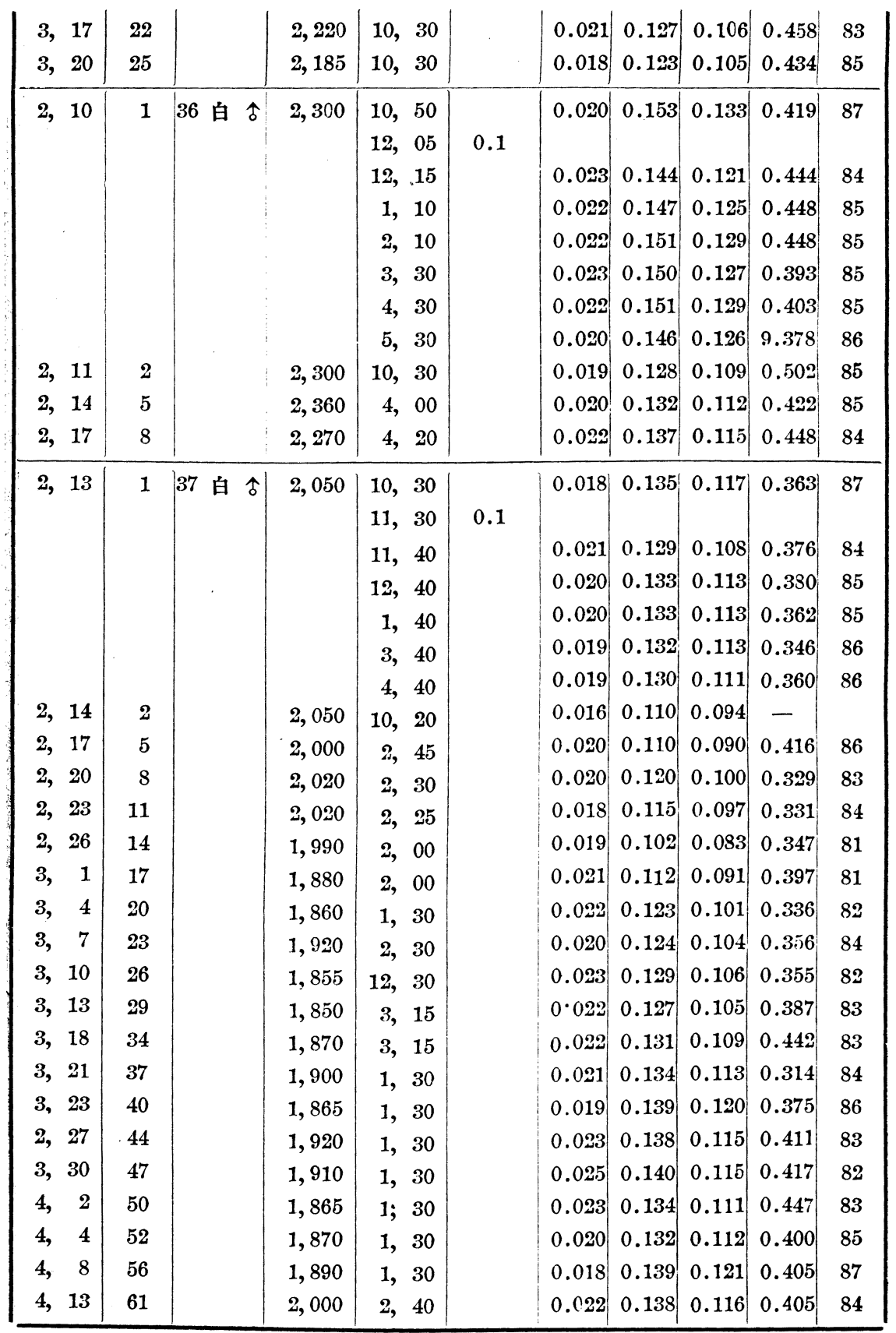


第

九

㽞

晹粘膜上皮細胞乳劑注入 (pro kilo 0.01) (38號)

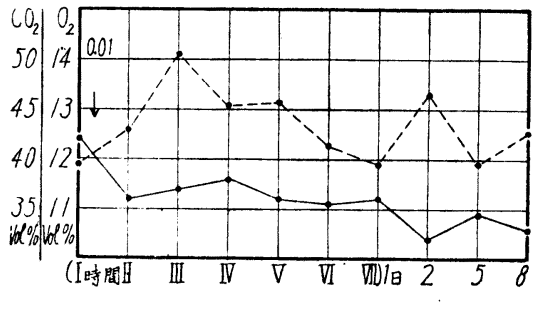

- - - 酸素容量

炭酸瓦斯含

有量

第十圈

腸粘膜上皮細胞乳䊾注入 (pro kilo 0.1) (37號)

酸素容最

炭酸瓦斯含有量

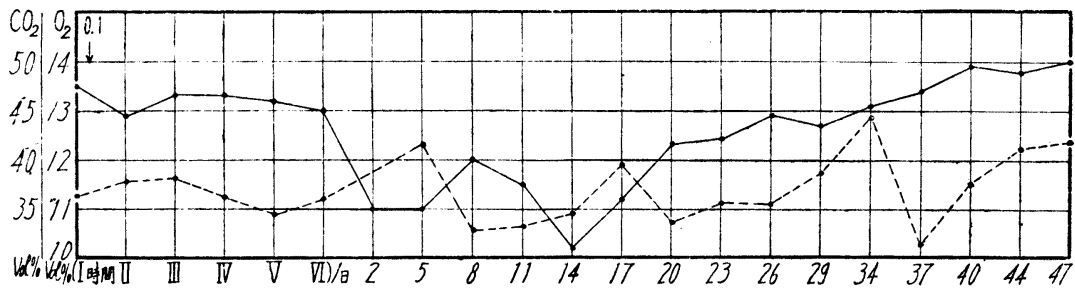

上皮紐胞成分 注入ニョリテ瓦斯血液量二何等著明ノ影響き與へズ。

\section{第四童 總括考按}

余八健康家鬼，腹膑内二異瑀性大動脈内被細胞成分キ注入シテ其，血液瓦斯二及ボ

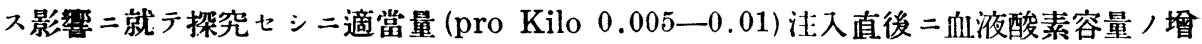
加丹認メ。之レト同時二炭酸瓦斯含有量八減少シ。酸素容量, 常態二復スル時二炭酸 瓦斯含有量モ常態二復セリ。郎于適當量，注入ニョリテ瓦斯代謝八一時促淮セラル。 次二大量 (pro Kilo 0.05-0.1) 注入直後二於テ八酸素容量，減少及ビ同時二炭酸瓦 斯含有量/增加 認ム。即チ大量注入ニヨリテ瓦斯代謝ハ一時抑制セラル。以上ノ變 化八注入郎日二惹起七ラル、モノニシテ第 2 日目二八酸素容量ノ減少ト炭酸瓦斯含有 量/增加卜タ認ムレドモ。コノ變化八對照健康家鬼二於テモ認メラル、モノニシテ第

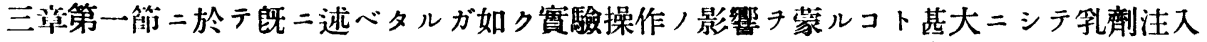
二因ル影辢ニアラザルモ，、如シ。第 2 日以後何等著變キ認メズ。

同種性腹膜.上皮細胞及ビ胃腸粘膜上皮細胞成分キ夫々健康家鬼, 腹腔内二注入シタ ルニ何レノ場合二モ其注入量，如何二關セズ注入直後二於テ酸素容量ノ增加テ來セル モノナク漱次減少シ。炭酸瓦斯含有量ハー一時增加シ更二減少ヨ來セリ。郎チ對照試驗 
832 佐藤＝非經口的 $=$ 注入七ル大動脈壁細胞成分，血㕓及血液瓦斯二及ボ ス影整二就テ

ニ於テハ瓦斯代謝ハ促進セラレズ反テ抑制セラレ第 2 日以後ノ變化ハ對照健康家鬼二 比較シテ著明ノ差異丹認メザリキ。實驗家鬼ノ一般狀態ニ於テハー時體重ノ隇少ア認 ムル外特二著明ナルモノナク。何レノ場合二モ家鬼ハョク長期，賽驗二堪ユルタ見タ リ。以上余, 實驗成績キ綜合スレバ生體二非經口的二大動脈內被細胞成分キ注入スル 時ハ對照諸實驗二比較シテ稍く特有ノ變化キ認ムルチ得タリ。郎于該成分八生體ノ血 管內被細胞二作用シ之チ刺戟シテ瓦斯代铸機能艺進尹來七ルモノト想像シ得べシ。余

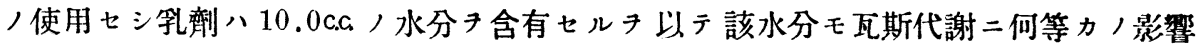
キ與フ可キニ非ザルカタ知ラント欲シ隇菌蒸餾水 10.0c.c. 健康家鬼二注入シテ (第三

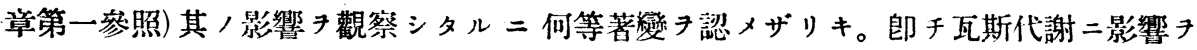
及ボスモノ八乳劑中ノ水分二八非ザル可シ。大動脈內皮細胞成分，注入量小ナル場合 ニ八何等認ム可キ變化ナキモ適常量 注入七バ瓦斯代謝機能立進三酸素, 攝取. 炭酸 瓦斯ノ排出作用キ强メ。大量注入ニアリテハ其ノ刺戟强キ二過ギ瓦斯代謝八障碍七う

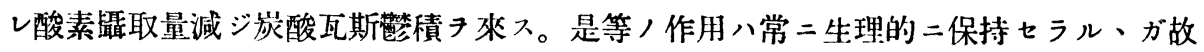
二適當量，刺戟二於テモ生理的以上ノ作用チ現ハスコト甚ダ困難ナルモ，、如ク其， 增加ノ程度ノ小ナル理由モ自ラ明カナルベシ。

翻テ考フル二血液中ニアリテ酸素へ大部分血中ノ血色素卜絬合シ其，割合八血色素 中ノ鐵一分子ト酸素一分子卜結合スベキナリ。然レドモHoppe-Seyler, Bohr 氏等二 依レバ血色素ノ酸素結合量ガ同一動物ニアリテモ幾分異ナルモノニシテ貧血ノ場合二 掹色素其ノモノ、酸素結合力ガ特二增加スト稱セリ。Morawitz, Plesch 氏等二低レ バ血色素ノ不足き補つモノ八血流ノ增進ニヨルト释セリ。然レドモ Lungs-Graad 氏 二依レバ督血ノ場合安静時二於テ血中ノ酸素ガ全部消費セラレザレバ循環ノ速度增加 セズ從テ血流增加ハ血色素 $30 \%$ 以下二低下七ザレバ起ラズト云へリ。是等/文跃タ 綜合スレバ酸素容量/增加八赤血球又ハ血色素ノ增加ノ結果ナラザルベカラズ。然ル 二余ノ實驗二於テハ大動脈内被細胞成分注入後酸素容量, 增加タ見タレドモ同時二赤 血球二就テ何等實驗スル所ナカリショ以テ其/增減ヲ識ル能ハズト踓モ赤血球新生機 一能六進八造血藏器/適當ナル刺戟ニヨルモノニシテ刺戟後一定時間/經過ニョリ初テ 赤血球增多キ來スベキモノニ：テ(小野)余ノ所見ノ如ク注入直後，變化八赤血球，戀 化二因ルモノ二非ザル可シ。血壓艺進シ血流旺盛トナレバ酸素含有量增加スベシ。然ル 二余，場合血厴八却テ降下，傾向 (第二篇參照) キ示シ血流八元進セラル、コトナカル 可シ。又呼吸障碍特二呼吸困難 フ起 ス場合二八動脈血酸素不䳌和度八增加 シ (加藤). 家兔，急性失血性貧血二於テ八動脈血酸素不飽和度八貿血前二比 シ幾分減少 (加藤) $、$ 
ト. 余ノ場合二八酸素不飽和度二著變ナク且一般狀態特二呼吸作用二何等著變き認メ ズ又貧血，度モ著明ナラ久゙從テ血液瓦斯八呼吸作用入八貧血等ノ影響き蒙ルコトナカ ルバシ。カク論ジ來タレバ血液瓦斯ノ變化ハ次ノ一事二因ラザル可カラズ。郎チ血管内

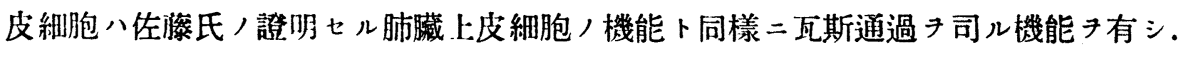
其ノモノ、狀態如何ニヨリテ或八瓦斯代謝促進セラレ或八障碍セラル可シ。勿論肺臟 瓦斯交換八肺藏与:皮紐胞機能卜相俟ツテ圓滑ナル生理作用キ營ム可キモノナルぶシ。 血管內被細胞ノ機能 左右スルモノ八種々, 要約き必要卜ス可キモ宮川敉授ノ唱導七 ラル、ガ如ク生體內二テ破壞セラレタル血管內被細胞成分ガ直接血管內被細胞二作用 シ滴當量ナル場合二八其，機能艺進シ瓦斯代謝ハ旺盛トナリ大量ナルトキ八其ノ機能 障碍七ラレ瓦斯代謝ハ減衰セラルべキ入余，實驗二徴シテ明白ナルべク．宮川敉授，

直接作用/學說八其/最モ適切ナル解釋ナリト信ズ。一旦增加セル酸素容量/減少七 ルハ一度え進七ル狀態二アル細胞八漱次疲勞, 狀態二達シ瓦斯代謝モ又障碍七ラレタ ルモノナルベシ。

\section{第五章 結 論}

余ノ實驗成績き摘要スレバ

1. 牛大動脈内被細胞乳劑子非經口的二健康家鬼二注入スル時八血液瓦斯含有量二 變化來不。

2. 家鬼二牛大動脈內被細胞乳剂 7 pro Kilo $0.005-0.01$ ，割合二非經口的二注 入スルトキハ動脈血酸素容量及ビ酸素含有量ノ增加き來ス。然レドモコノ變化八時間 ノ經過スル二從七溸次減少ス。

3. 家鬼二牛大動脈內被細胞乳乵子 pro Kilo 0.05-0.1 割合二非經口的二注入 スルトキハ動脈血酸素容量及ビ酸素含有量ノ減少き來ス。然レドモコノ變化ハ時間， 經過卜共二漱次恢復入。

4. 前記酸素容量及ビ酸素含有量/增加又ハ減少ノ時期二略々一致シテ血液炭酸瓦

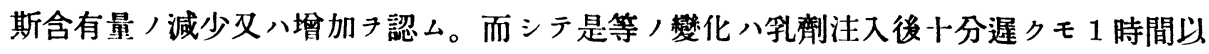
內ニえき證明シ得べシ。

5. 對照試驗 (水. 腹膜. 胃腸上皮細胞成分注入) 二於テ其／注入量／如何二關七ズ 動脈血酸素容量及ビ酸素含有量ノ增加ハ一般二認メズ。加之往々其 /減少き來セル事 アリ。炭酸瓦斯含有量，變化モ著明ナラザルガ如シ。

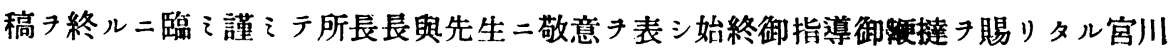


数授二婁心感謝入。

\section{文}

1) Krogh, Anatomie u. Physiologie d. Cappillaren. 1926. 2) Barcroft, The respiration of the blood. Cambridge. 1914. 3) Haldane, Douglass \& Haldane, J. of physiol. 44. 353. 1912. 4) Schjering, Beitr. z. Klin. d. Tuberculose u. spezif. Tuberculose-forschung.

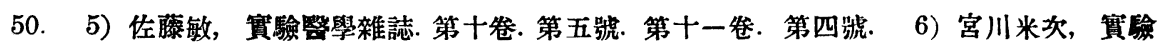

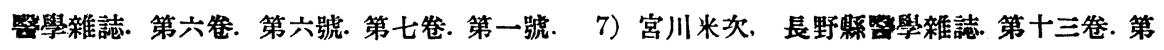

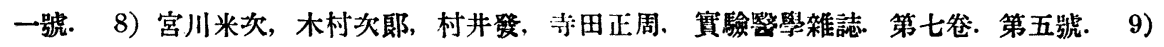
Dungern, Münch. Med. Wochenchr. 38. 1228. 1899. 10) 町田三郎, 繁事新開. 1261 號. 1930. 11) 米山義雄, 國民衙牛. 第二衮. 第入號. 12) Barcroft \& Robert, J. of physiol. 39. p. 429. 1909-10. 13) Hoffmann. J. of physiol. 47. p. 272. 1913-14. 14) Bohr, Tiegerstedts Handb. d. physiol. Methodik. Bd. 2. Häfte. 1. 1911. 15) Bürker, ibid. Bd. 2. Häfte 1. 1911. 16) 小金井良一, 生化學微量定量法. 1926. 17) Pincussen, Mikromethodik. 1928. 18）北村武雄, 愛知䛓學會雜誌. 第三十五卷. 第四號. 19) Hasselbach, Bioch. Zeitschr. 46. S. 403. 1912. 20) Evans, Brit. J of Exp. Path. 2. 3. p. 105. 1921. 21）佐藤亭, 日新嫛學. 第十一替. 第十二號. 第十二卷. 第一號. 22) 大森 千束, 北越醫學會雜誌. 三十六年. p. 254. 23) 楠正信, 東京整學會雜誌. 第二十九巷. 第十

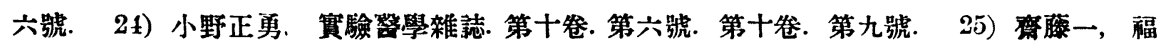
岡醫學會雜誌. 第十三卷. 第四號. 26) Tatum, J. of Bioch. Chem. 41. 1920. 27) 大本最,

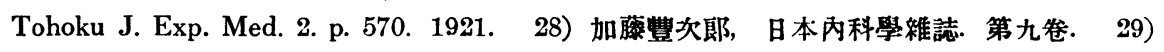
Naegeli, Blutkrankheiten u. Blutdiagnostik 1919. 30) Masing u. Siebeck, Arch. f. klin. Med. 99. S. 130. $1910 . \quad 31)$ Hoppe-Seyler, Zeitschr. f. physiol. Chem. 13. S. 477.1889. 32) Bohr, Skand. Arch. f. Physiol. 3. S. 101. 1892 . 33) Morawitz u. Röhmer, Deut. Arch. f. Klin. Med. 94. S. 529. 1908. 34) Plesch, Zeitschr. f. exp. Path. u. Ther. 6. S. S. 380.1909. 